\title{
The macrosemiiform fish companion of the Late Jurassic theropod Juravenator from Schamhaupten, Bavaria, Germany
}

\author{
Gloria Arratia* and Hans-Peter Schultze \\ Biodiversity Institute, Natural History Museum, The University of Kansas, Dyche Hall, Lawrence, Kansas 66045-7561, U.S.A.; \\ E-mail: garratia@ku.edu; hp1937@ku.edu
}

Received 1 April 2011

Accepted 19 August 2011

Published 21 February 2012

\section{Key Words}

Southern Germany

Systematics

Actinopterygian fishes

Anatomy

Taxonomy

\begin{abstract}
A new neopterygian fish, Voelklichthys comitatus n. gen. n. sp., is described. The fish was found during the preparation of the theropod Juravenator starki Göhlich \& Chiappe, 2006 in the same rock. The fish possesses numerous autapomorphies. The combination of autapomorphies is unique among Jurassic fishes and makes its taxonomic assignment difficult. The following characters are few examples demonstrating some of the peculiarities of the fish: The fish is small, oblong-shaped and has a large triangular head that is deeper than long; deepest point is at the level of the postparietal bone [parietal of traditional terminology] and the ventral end of the cleithrum. The skull roof is almost vertically oriented, with a strongly ossified and developed anterodorsal orbital margin. Premaxilla and dentary possess very small conical teeth. The opercular apparatus is markedly narrow and deep. A clavicle is present. Both dorsal and ventral postcleithra are almost as deep as the maximum depth of the head; the dorsal postcleithrum is two times deeper than the ventral one. The vertebral centra are of arcocentral-type formed mainly by the development of the dorsal arcocentra. Pectoral and pelvic fins possess long rays that extend onto the pelvic and anal fins, respectively, whereas the rays of the dorsal and anal fins extend onto the caudal fin. The fish is interpreted as a macrosemiiform because it presents two of the three synapomorphies of the group (e.g., an incomplete circumorbital ring because the lateral edge of parietal bone [frontal of traditional terminology] makes up part of orbital margin and absence of a supramaxillary bone). The third macrosemiiform synapomorphy cannot be determined in the new fish because the coronoid bones and their dentition are not observed due to condition of preservation. The new fish shares a few characters with members of the families Macrosemiidae and the Uarbryichthyidae but lacks others so that presently, we place it in a family indeterminate within Macrosemiiformes.
\end{abstract}

\section{Introduction}

Numerous fossils were recovered during the excavations in the quarry in the Schambachtal near Schamhaupten, Bavaria, between 1989 and 1998 conducted by the Jura-Museum Eichstätt, Bavaria, Germany with support of the Friends of the Jura-Museum Eichstätt. The brothers Hans-Joachim ( $\dagger$ ) and Klaus-Dieter Weiss, who worked as volunteers in Schamhaupten, found an outstanding reptile that was recovered in many pieces in August 1998. The specimen required the skills of a professional preparator familiar with the fossils of the region to expose the animal in its whole magnificence, and the preparation was entrusted to Mr. Giuseppe Völkl who has extensive experience with these fossils. G. Viohl, the director of the Jura-Museum at that time, communicated this finding in a short communication (Viohl 1999). He briefly described the conditions, in which the fossil was found and also the characteristics of the rock ("as hard as steel"), that make the preparation of fossils of Schamhaupten an extremely difficult task. Later, the fossil was described as Juravenator starki by Göhlich \& Chiappe (2006) (see also: Göhlich et al. 2006; Tischlinger et al. 2006; Chiappe \& Göhlich

\footnotetext{
* Corresponding author
} 
2010). This small reptile "is one of the most complete non-avian theropod skeletons described to date for Europe, and a significant addition to the scant worldwide record of small-bodied Late Jurassic theropods" (Chiappe \& Göhlich 2010, p. 291).

During the preparation of Juravenator starki, Mr. Völkl found a small fish among the discarded rock pieces, which he checked one by one, but he did not find any other fossil. The fish appeared to be something very unusual for someone like him familiar with the preparation of fishes of the Solnhofen limestones. He prepared the small specimen and presented it to G. Arratia during one of her frequent visits of the JuraMuseum Eichstätt.

Numerous fossils showing a broad diversity were recovered during the scientific excavations in Schamhaupten. These include plants, microfossils, sponges, corals, gastropods, bivalves, cephalopods, bryozoans, brachiopods, polychaetes, arthropods, echinoderms, fishes, marine reptiles, and Juravenator as single terrestrial reptile (Viohl \& Zapp 2006). The fishes represent the most diverse group; 39 fish taxa were reported by Viohl \& Zapp (2006) in their preliminary identification and evaluation of the fossil content of Schamhaupten. Many of the fish identifications were left at the genus or higher taxonomic level due to the fact that many of the taxa show some differences with fish taxa described from other localities of the same or different ages in the Solnhofen limestones. However, among the numerous fishes collected in Schamhaupten none was comparable to the small fish recovered together with Juravenator.

The locality of Schamhaupten is placed in the uppermost Kimmeridgian, Late Jurassic (Fig. 1). Recently it has been assigned to the late Kimmeridgian Hybonoticeras beckeri Zone, Lithacoceras ulmense Subzone (Neochetoceras rebouletianum horizon) on the base of ammonites (Schweigert 2007). Although numerous fishes have been recovered in the locality, only a few have been formally described, for instance, a member of the Siemensichthys-group (Siemensichthys siemensi Arratia, 2000a), an ichthyodectiform (Ascalabothrissops voelkli Arratia, 2000b), and an elopomorph (Anaethalion zapporum Arratia, 2000b). A semionotiform, Lepidotes sp., was described in detail by Thies \& Zapp (1997), but a specific name was not given by the authors in consideration that the genus Lepidotes was in need of revision. López-Arbarello \& Sferco (2011) erected and named the new species Scheenstia zappi largely based on Thies \& Zapp's (1997) studies.

The goal of this paper is to describe a new macrosemiiform fish from the upper Kimmeridgian of Schamhaupten, which was found in the same block as Juravenator starki, and discuss its inclusion among macrosemiiforms and the current state of knowledge of the group. During our project, and as a result of the

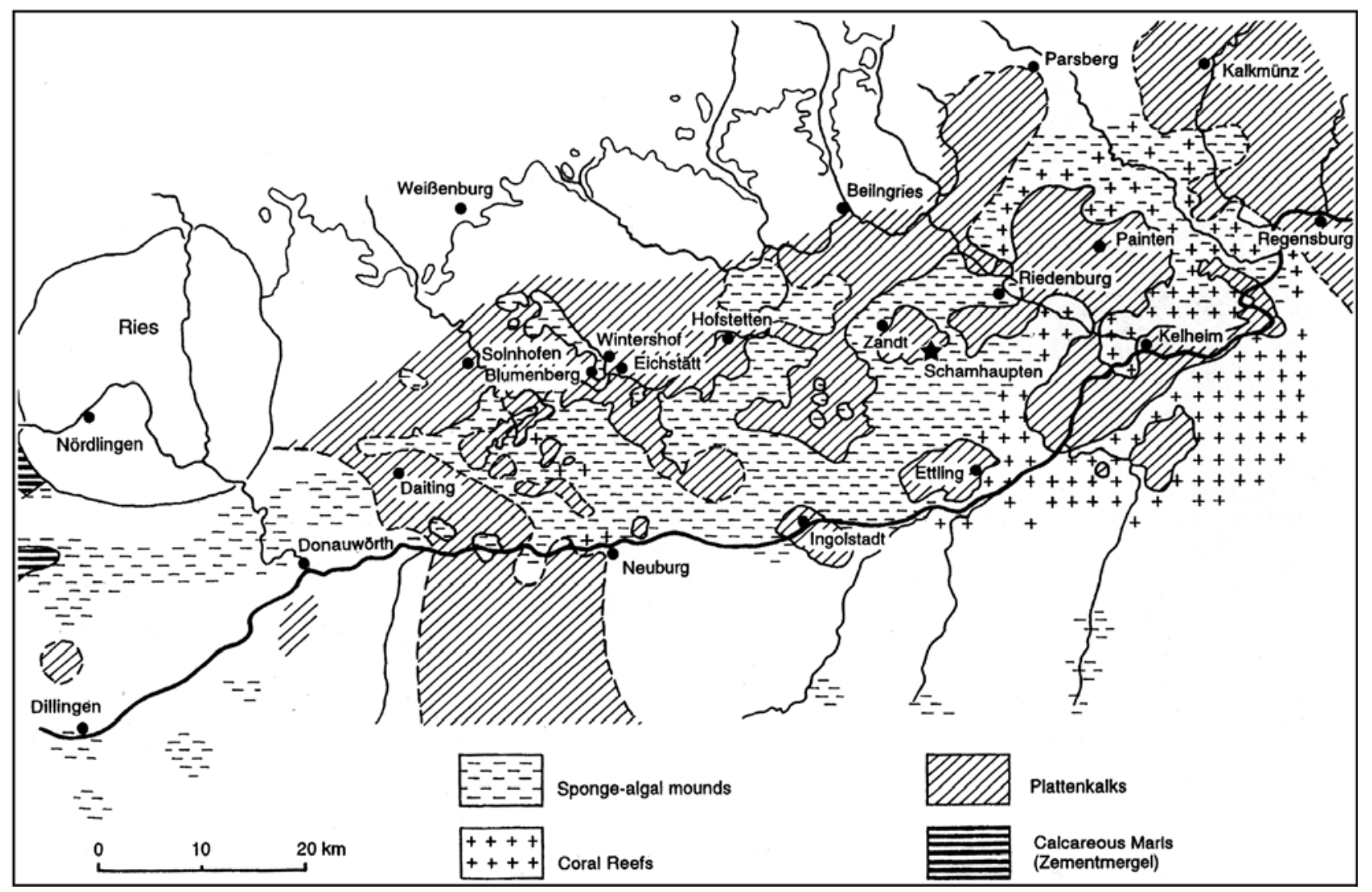

Figure 1. Distribution of Plattenkalk basins and reef areas in the southern Franconian Alb during Kimmeridgian/early Tithonian (slightly modified from Viohl 1996). The macrosemiiform described here was recovered in Schamhaupten (indicated by a star). 
comparative morphological studies, we gathered new information concerning macrosemiiforms, and also we have identified areas that need further research. A section on selected comparative morphological characters of macrosemiiforms is included.

\section{Material and methods}

A broad survey of young and adult actinopterygians, especially neopterygians, was made trying to identify and solve the taxonomic position of the fish described here. Young and adult teleosts also were studied. The survey includes all neopterygian taxa described up to now for the Jurassic times. The survey was also extended to fishes with long fins such as flying fishes (from different geological periods), but the results demonstrated that the fish described here has very different cranial configuration to the flying fishes (e.g., Beltan 1984, 1996; Tintori \& Sassi 1992) so that this comparison was not extended further. Special efforts were dedicated to Jurassic fishes from the area of Bavaria deposited, among others, in the Jura-Museum in Eichstätt, the Bürgermeister-Müller-Museum in Solnhofen, the Bayerische Staatssammlung für Paläontologie und Geologie, München, the Museum für Naturkunde in Berlin and the NaturkundeMuseum in Bamberg. The Jura-Museum in Eichstätt has the largest collection of fossil material from Schamhaupten (JM-E SCH). No macrosemiids are represented among the material, and no other fish, small or large, that could be comparable the fish described here. Holding of macrosemiids from the Solnhofen limestones in the above mentioned museums and in other museums were revised.

The specimen was mechanically prepared and studied under a series of stereomicroscopes with different resolution power (Leica M165C, and Wild M4 and MZ8) and a compound Olympus microscope with laterally directed light. The specimen was photographed under white light and also with UV techniques (Tischlinger 2002, 2005). UV techniques discovered some major additional morphological details of Juravenator to those provided by the white light alone (e.g., Göhlich et al. 2006; Tischlinger \& Göhlich 2007). The study of the new fish described here has not provided any additional information under UV techniques even though the specimen was discovered in the same rock as Juravenator.

\section{Institutional abbreviations}

AM - Australian Museum, Sydney, New South Wales, Australia; BMNH - Natural History Museum (former British Museum (Natural History)), London, United Kingdom; BSP - Bayerische Staatssammlung für Paläontologie und Geologie, München, Bavaria, Germany; JM-E - Jura-Museum Eichstätt, Bavaria, Germany.

\section{Terminology}

The terminology of the skull roof bones is based on homologization of bones and follows the criteria outlined in Westoll (1943), Jollie (1962), Schultze (1993, 2008), and Wiley (2008). To avoid possible confusion of names with those of the traditional terminology, those of the traditional terminology are presented in parentheses the first time that the name is cited and also in the illustrations. Names of vertebral elements follow Schultze \& Arratia (1989); Arratia (1997); Arratia et al. (2001). Names and abbreviations used in the identification of different fin rays are those in Arratia (2008). All illustrated scales presented here are from unpublished data of H.-P. Schultze and from Schultze (1966). The terminology used in the scales follows Schultze (1966, 1996). The high level classification of actinopterygians follows Wiley \& Johnson (2010, p. 126), and that among Neopterygii is from Grande (2010).

\section{Systematic Paleontology}

Class Actinopterygii Cope, 1887

Subclass Neopterygii Regan, 1923

Infraclass Holostei Müller, 1845 [sensu Grande, 2010]

Cohort Ginglymodi Cope, 1872 [sensu Grande, 2010]

Order Macrosemiiformes Carroll, 1988

Family indeterminate

\section{Voelklichthys n. gen.}

Diagnosis (based on a unique combination of characters; unique characters among macrosemiiforms are identified with an asterisk [*]). Very small macrosemiiform, oblong-shaped $\left[{ }^{*}\right]$, with a large triangular head deeper than long; deepest point at the level of the postparietal bone and ventral end of cleithrum/clavicle [ $\left.{ }^{*}\right]$. Skull roof almost vertically oriented $\left[{ }^{*}\right]$. Strongly ossified and developed antero-dorsal orbital margin of parietal bone [*]. Well-developed dermosphenotic sutured with both parietal and dermopterotic. Supraorbital bones absent. Premaxilla and dentary with small conical teeth [ $\left.{ }^{*}\right]$. Articulation between lower jaw and quadrate placed below posterior half of orbit. Narrow and deep opercular apparatus. A pair of extrascapular bones carrying extrascapular canal. Arcocentral-type of vertebral centra formed mainly by development of dorsal arcocentra [*]. Neural spines of caudal region simple, with no separated halves [*]. A clavicle present. Enlargement of both dorsal and ventral postcleithra that together are almost as deep as the maximum depth of head [ $\left.{ }^{*}\right]$. Origin of dorsal fin at half length of standard length [*]. Dorsal fin undivided. Pectoral and pelvic fins with long rays extending onto the pelvic and anal fins, respectively, and dorsal and anal fins extending onto the caudal fin $\left.{ }^{*}\right]$. All fin rays long based.

Etymology. Voelklichthys honoring the work of Mr. Giuseppe (Pino) Völkl as preparator in the Jura-Museum Eichstätt from 1976 to the beginning of 2010, including among others the preparation of numerous fishes studied by G. Arratia and for the finding and carefully preparation of the holotype, and - ichthys (Greek) for fish.

\section{Voelklichthys comitatus n. sp.}

Figures 2-6

Diagnosis. Same as generic diagnosis.

Holotype and only specimen. JM-E SCH 102 is an almost complete specimen of $24.09 \mathrm{~mm}$ in length, missing the distal tips of caudal fin rays (Figs 2, 3). A few displaced scales are exposed above the caudal fin. The preserved head bones, the neural and haemal arches and spines and fins, are heavily ossified despite the fact that the specimen is very small. Presently, we interpret the specimen as a possible small-sized subadult or adult, based on bone ossification (see below for explanations).

Type locality and age. Quarry Stark in the Schambachtal near Schamhaupten, Bavaria, Germany (Viohl \& Zapp 2006; Viohl 2007); Late Jurassic, Kimmeridgian, Hybonoticeras beckeri Zone, Lithacoceras ulmense Subzone (Neochetoceras rebouletianum horizon) (Schweigert 2007).

Etymology. The species name comitatus, Latin for accompanying, refers to the co-occurrence of the fish specimen with the theropod Juravenator starki.

\section{Description}

The large head is almost rhomboidal in shape with the deepest section at the level of the most dorsal, medial 


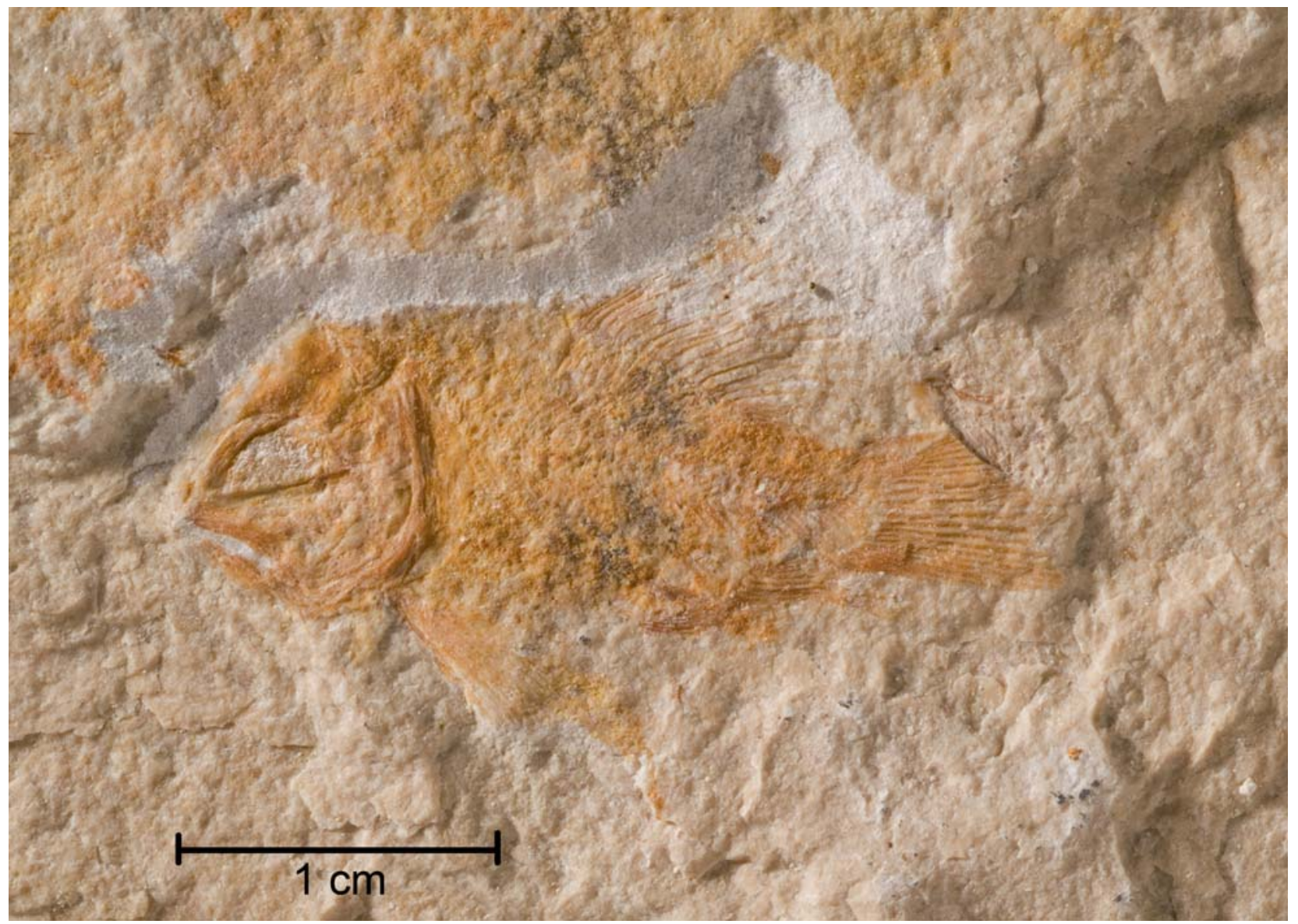

Figure 2. Voelklichthys comitatus n. gen. n. sp. from the Kimmeridgian of Schamhaupten, Bavaria, Germany. Lateral view of complete specimen JME SCH 102.

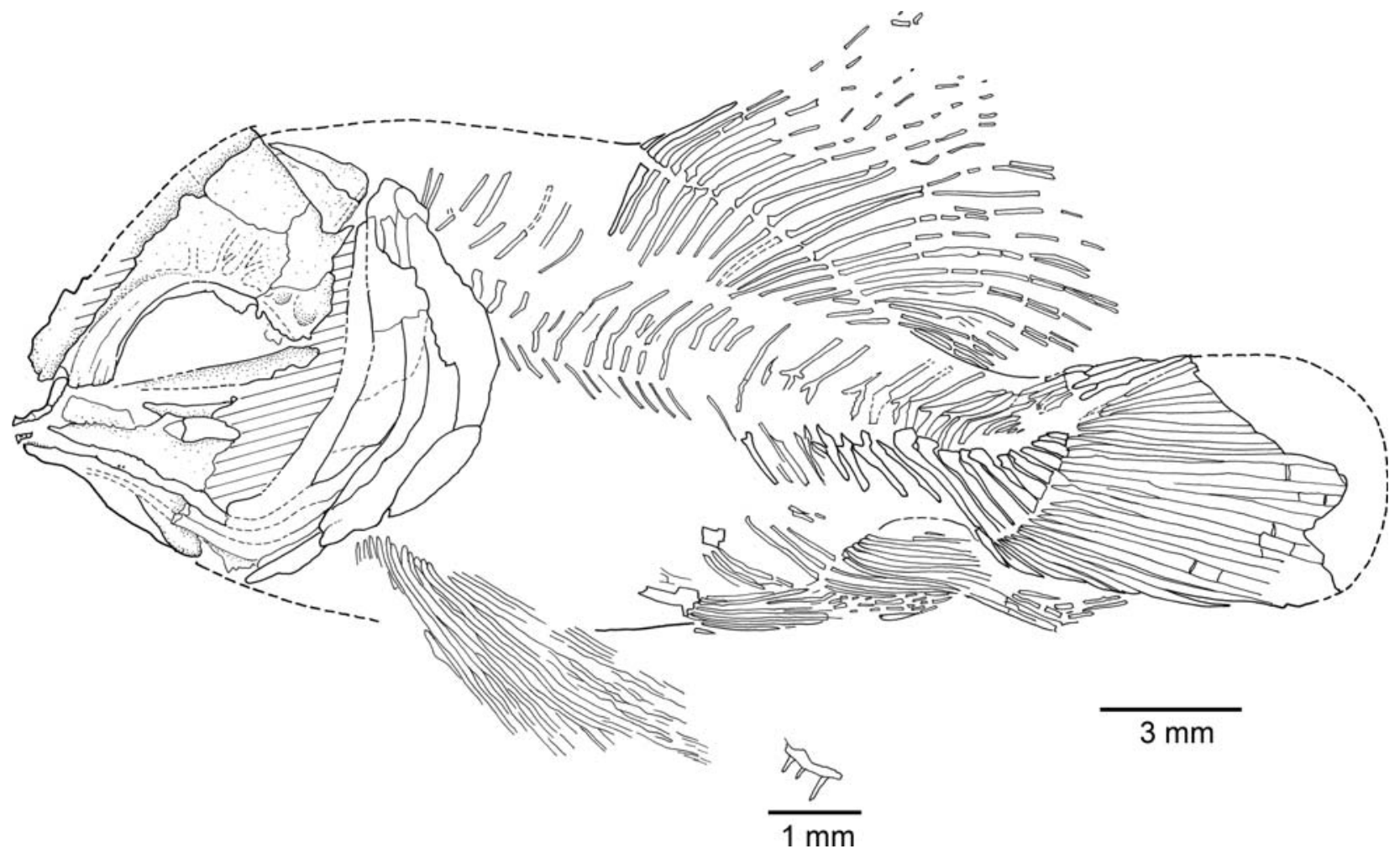

Figure 3. Drawing of Voelklichthys comitatus n. gen. n. sp. in lateral view based on the holotype JME SCH 102 and enlargement of a displaced premaxilla found in the illustrated position. Oblique lines represent broken areas in the head. 


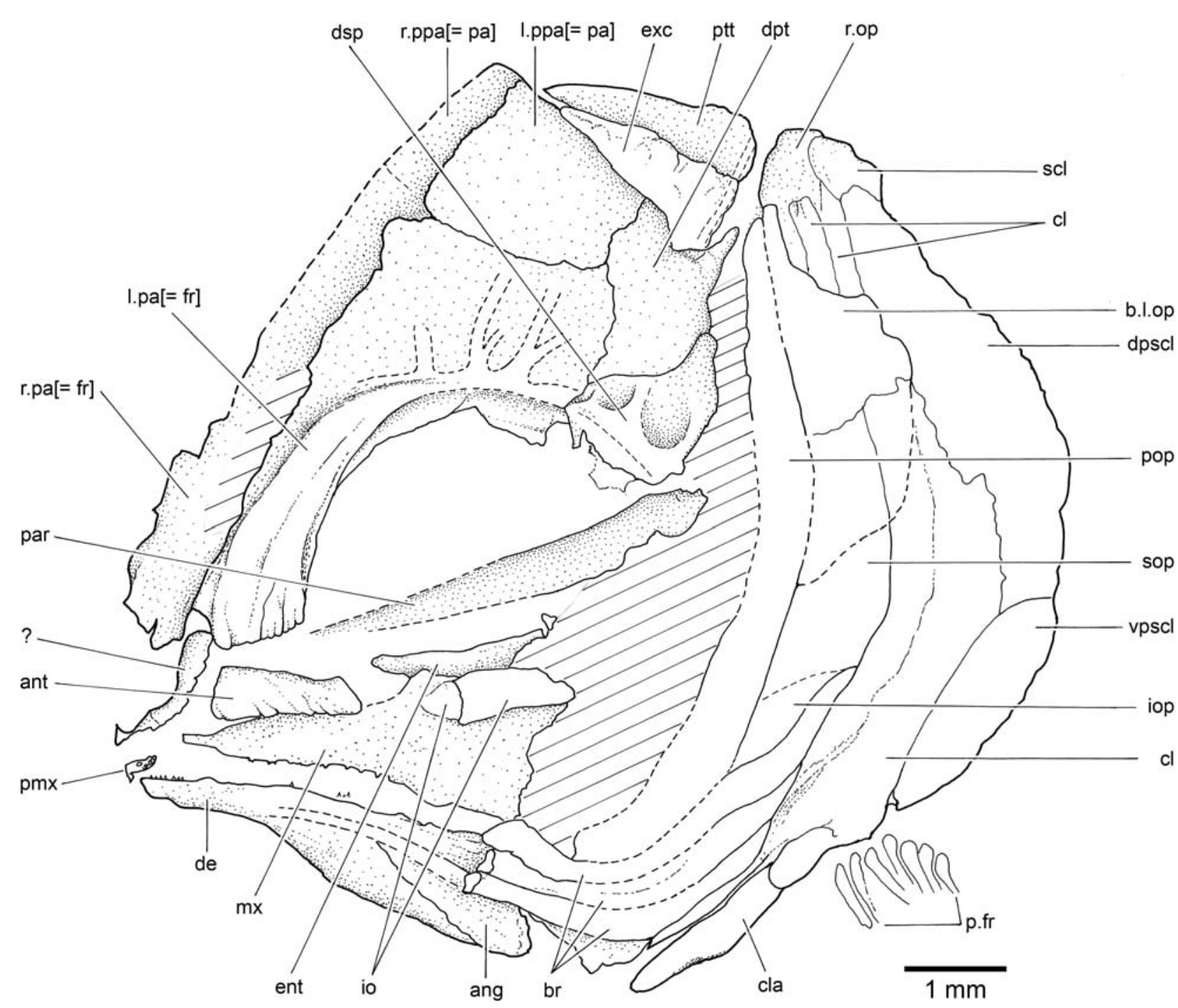

Figure 4. Voelklichthys comitatus n. gen. n. sp. (JME SCH 102). Head and pectoral girdle in lateral view. Oblique lines represent broken areas in the head. Abbreviations: ant - antorbital; ang - angular; b.l.op - broken left opercle; br - branchiostegal rays; cl - cleithrum; cla - clavicle; de - dentary; dpcl - dorsal postcleithrum; dpt - dermopterotic; dsp - dermosphenotic; ent entopterygoid; exc - extrascapula; io - infraorbital bone; iop - interopercle; l.pa[= fr] - left parietal bone [= frontal bone of traditional terminology]; l.ppa[= pa] - left postparietal bone [= parietal bone of traditional terminology]; mx - maxilla; par parasphenoid; p.fr - pectoral fin rays; pmx - premaxilla; pop - preopercle; ptt - posttemporal bone; r.op - right opercle; r.pa[= fr] - right parietal bone [= frontal bone of traditional terminology]; r.ppa[= pa] - right postparietal bone [= parietal bone of traditional terminology]; scl - supracleithrum; sop - subopercle; vpcl - ventral postcleithrum; ? - unidentified bone.

corner of the postparietal $[=$ parietal of traditional terminology] to the most ventral point of the cleithrum/ clavicle (Fig. 4$)$. The depth is slightly larger ( $108 \%)$ than the length of the head measured from the anterior tip of the head to the posterior preserved border of the opercle. The skull roof is almost vertically oriented. The angle of the skull roof in relation to the almost horizontally oriented upper margin of the maxilla is $\sim 60^{\circ}$, whereas the angle between the ventral margin of the lower jaw and the skull roof is $\sim 90^{\circ}$. The jaws are moderately long, and the articulation between lower jaw and quadrate is placed at the level of the posterior half of the orbit. The opercular bones are markedly narrow and deep based on an interpretation of the incomplete preserved bones of this region, and the space left between the orbit and cleithrum. An outstanding character is the enlargement of both postcleithra that together are almost as deep as the maximum depth of the head.

The holotype is $29.04 \mathrm{~mm}$ in total length (to the end of the incompletely preserved caudal fin rays) and $22.82 \mathrm{~mm}$ in standard length (from the tip of the snout to the posterior end of the hypurals). The head is $\sim 43 \%$ in standard length, with eyes relatively large; their diameter is $\sim 40 \%$ in head length. The caudal peduncle is narrower than the rest of the body ( $\sim 28 \%$ of maximum depth of the body). The dorsal fin is positioned at $\sim 58 \%$ of the standard length, whereas the pelvic fins are positioned posteriorly $(\sim 69 \%$ of standard length). The dorsal fin is long reaching from 58 to $86 \%$ of standard length. The origin of the anal fin is 


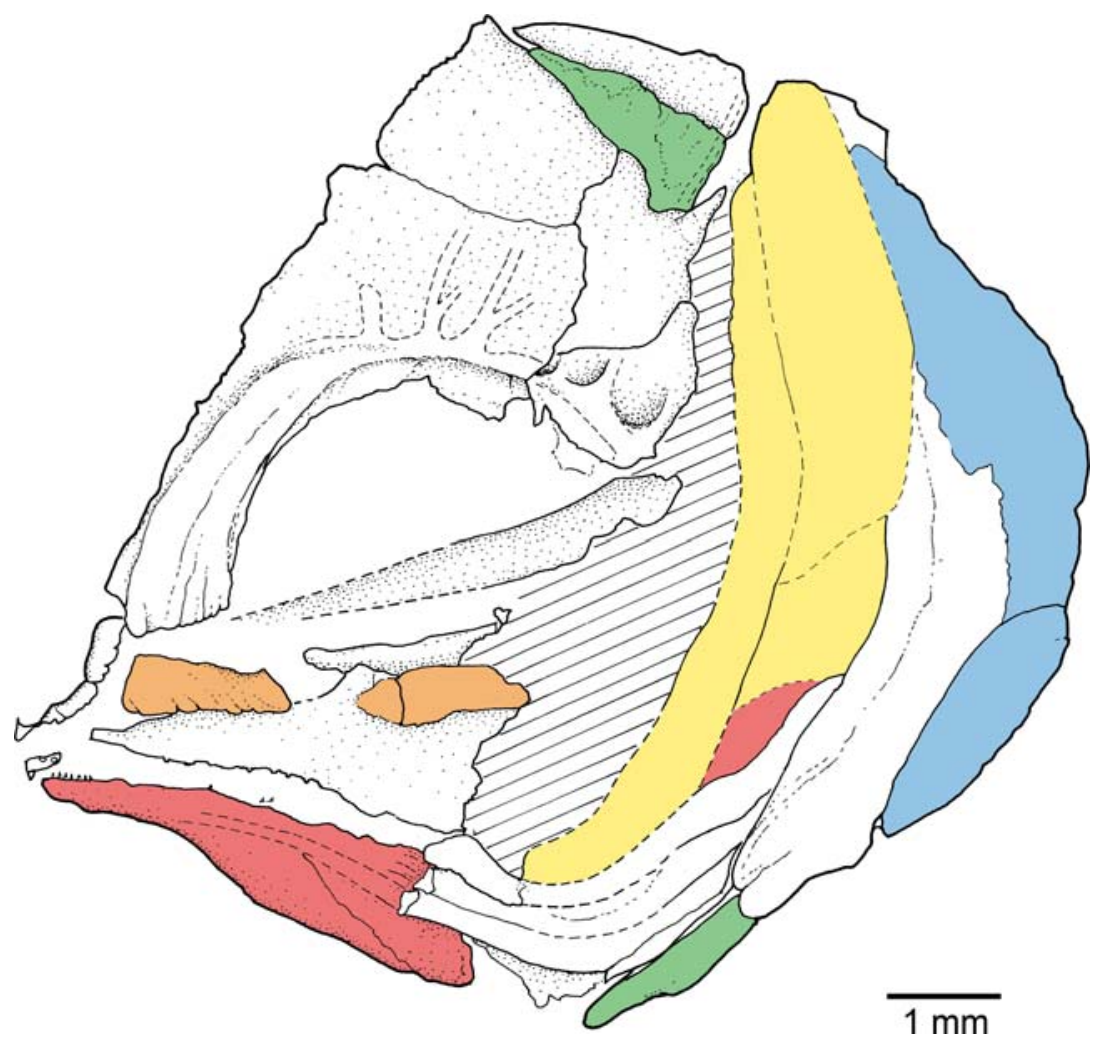

Figure 5. Diagrammatic representation of the cranium and pectoral girdle of Voelklichthys comitatus n. gen. n. sp. illustrating the narrow area occupied by the opercular series (in yellow), the position of the interopercle versus lower jaw (in red), infraorbital bones (in orange), clavicle (in green), and postcleithral region (in blue). $\sim 81 \%$ of the standard length; the beginning of the anal fin lies under the posterior part of the dorsal fin.

The cranial bones have a very thin cover of ganoine and lack ornamentation.

Braincase. The main element of the skull roof (Fig. 4) is the parietal bone $[=$ frontal bone of traditional terminology], which is broadly expanded laterally in its postorbital region where it is almost rectangular. Its orbital margin is strongly ossified. Both parietal bones join each other medially by an almost straight suture (or sutura harmonica). Each bone articulates posteriorly with a postparietal $[=$ parietal bone of traditional terminology], and laterally with the dermosphenotic and dermopterotic. All sutures between these bones involve smooth surfaces like that joining both parietals. Remnants of a broken, curved bone are preserved in front of both parietals. The identification of this element is not possible at the moment. It could be part of a long rostral bone or be part of a broken nasal bone. The parietal bone has an almost straight anterior margin that is slightly crenulated. The supraorbital sensory canal is enclosed in bone and anteriorly runs closer to the medial region than to the lateral margin of the bone, but posteriorly the canal gets closer to the orbital margin. The supraorbital canal gives off at least three tubules of slightly different lengths that extend medially and posteriorly. The supraorbital canal extends laterally into the dermosphenotic.

A nasal bone has not been observed and according to the pathway of the supraorbital canal and the anterior shape of the parietal bone, it is difficult to imagine where the nasal bone was located.
The left postparietal (Fig. 4) is a square-shaped bone suturing at its medial margin with the right postparietal through a smooth suture. Its posterior margin is partially covered by the anterior border of the extrascapula. The parietal branch/tubule of the supraorbital sensory canal does not reach the postparietal. No pit-lines have been observed on the postparietal and on any other bone. The postparietal laterally sutures with the dermopterotic, whose exposed dorso-lateral surface is small in comparison to other skull roof bones; however, the dermopterotic projects below the extrascapula and extends laterally and ventrally. We are unable to report the course of the otic canal due to conditions of preservation.

The dermosphenotic (Fig. 4) sutures with both the parietal and the dermopterotic. The dermosphenotic is well developed and almost triangular-shaped forming a significant part of the lateral wall of the postorbital region of the braincase. Remnants of three canals (the supraorbital, the infraorbital and the otic) are confluent in this bone.

A supraoccipital is absent according to the pattern shown by the preserved skull roof bones of the dorsoposterior region of the cranium.

An elongated, moderately narrow and triangular extrascapular bone (Fig. 4) lies on the posterior margin of the postparietal bone and on the dermopterotic laterally. The posterior margin is slightly undulated, whereas the anterior margin of the bone is smooth. The extrascapular or supratemporal canal runs bony enclosed near the anterior margin of the bone. A triangular posttemporal bone is positioned posterior to the extrascapula (Fig. 4); the lateral line canal or postotic canal runs bony enclosed near the lateral margin of the bone. 


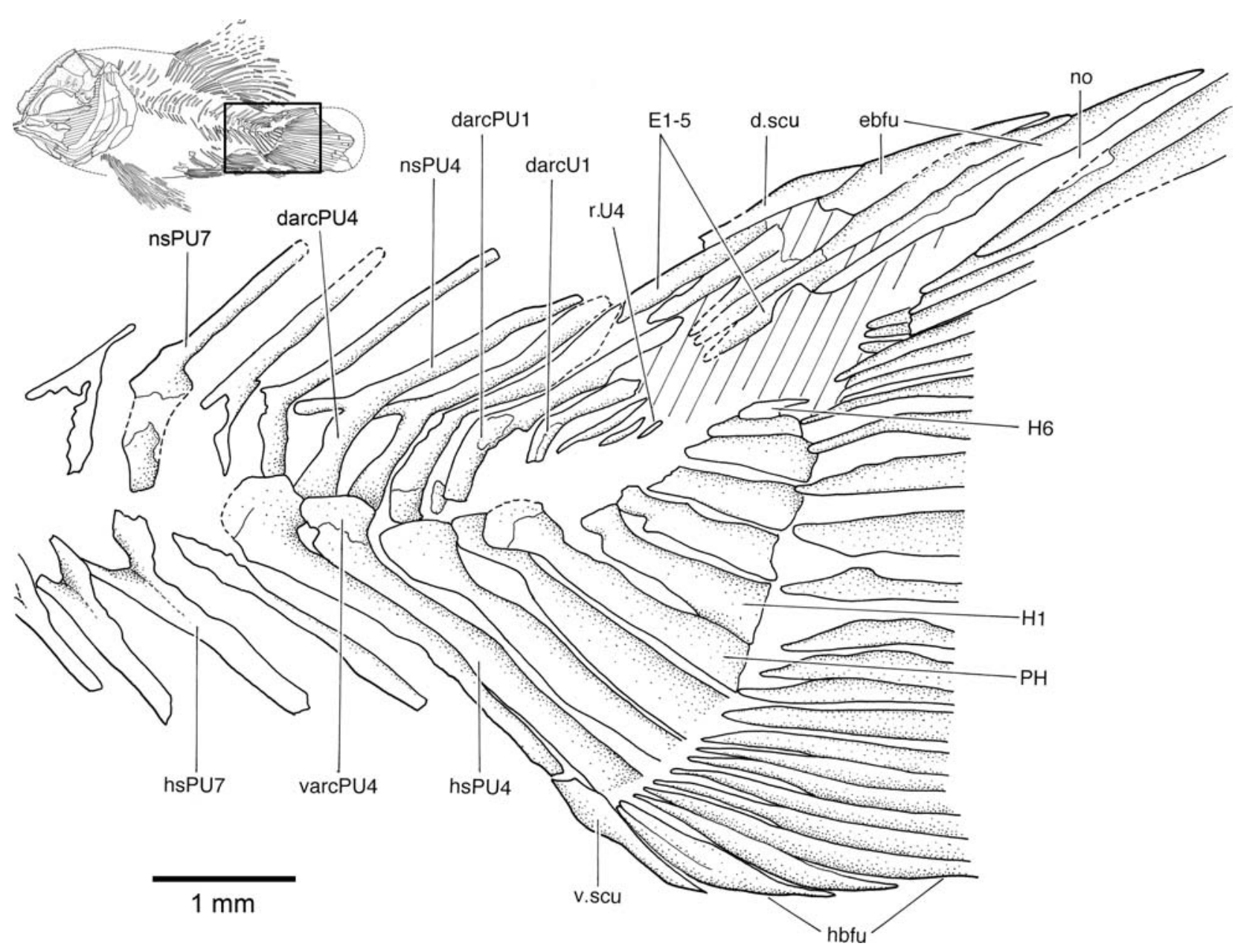

Figure 6. Voelklichthys comitatus n. gen. n. sp. (JME SCH 102). Posterior part of vertebral caudal region including caudal skeleton in lateral view. Oblique lines represent broken areas. Abbreviations: darcPU4, PU1 - dorsal arcocentra of vertebra PU4, PU1; darcU1 - dorsal arcocentra of ural vertebra 1; d.scu - dorsal caudal scute; E1-5 - epurals 1-5 (numbering of epurals implies number of elements, not homology); ebfu - epaxial basal fulcra; eU4 - element representing part of ural vertebral segment 4; H1, 6 - hypurals 1, 6; hbfu - hypaxial basal fulcra; hsPU7, PU4 - haemal spine of preural vertebra 7, 4; no - notochordal space; nsPU4, 7 - neural spine of preural vertebra 4, 7; PH - parhypural; varcPU4 - ventral arcocentrum of preural vertebra 4; v.scu - ventral caudal scute.

From the base of the braincase only part of the parasphenoid (Fig. 4) is preserved in ventral view. It seems to be a broad bone but no description is allowed due to its incomplete preservation. No teeth have been observed.

The postorbital region of the braincase is interpreted here as moderately short and slightly curved dorsally taking in account the preserved cranial bones and their positions, and the position of the anterior part of the vertebral column.

Circumorbital series. The fish lacks supraorbital bones. Their absence may be explained by the broadness of the orbital margin of the parietal bone. The bone interpreted here as an antorbital (by comparison to its position in other macrosemiiforms) is rectangular and narrow, slightly overlapping part of the dorsal margin of the maxilla, and extending broadly below the antero-lateral margin of the parietal bone (Fig. 4). The lateral surface is smooth and the trajectory of the infraorbital canal is not observed. All other infraorbital bones are damaged, but lateral to the dorsal part of the maxilla lies a bone that seems to be tube-like and probably corresponds to one infraorbital bone. Remnants of an infraorbital bone are placed below the dermosphenotic. The infraorbital canal seems to be bony enclosed. It is not possible to have an idea of how many infraorbital bones are present because of incomplete preservation.

Upper Jaw. The upper jaw (Fig. 4) is represented by the premaxilla and maxilla. A tiny, thin premaxilla is incompletely preserved just antero-dorsal to the symphysis of the lower jaw. One small conical tooth and remnants of a few other small teeth are observed. A displaced premaxilla is found ventral to the pectoral and pelvic fins (Fig. 3). It is unclear if the bone belongs to the same specimen, but because of its size and characteristics we assume that it belong to the same species. The displaced premaxilla bears three teeth that are elongated, with a distal conical tip. The maxilla is narrow anteriorly, with a slender and short articular process. It expands broadly posteriorly, and apparently, 
it does not cover laterally the quadrate. The oral border of the maxilla is almost straight and although teeth are not preserved, the oral border gives the impression of the presence of sockets for teeth.

Lower jaw. The lower jaw (Fig. 4) is also narrow anteriorly, but it gently deepens posteriorly, producing a marked curvature at its anterior half. Two bones, dentary and angular, are shown laterally. It is unclear, due to conditions of preservation, if a retroarticular bone forms the postero-ventral corner of the jaw and whether a surangular bone was present at the postero-dorsal corner of the jaw. The dentary occupies most of the length of the lower jaw; it projects ventro-posteriorly below the angular but it does not reach the posterior corner of the latter bone. It carries a row of minuscule conical teeth near the symphysis. The mandibular sensory canal (Fig. 4) is bony enclosed and runs closer to the oral margin of the dentary than to the ventral margin of the jaw. The postero-dorsal part of the lower jaw is covered by some displaced, broken branchiostegal rays so that the bones articulating with the lower jaw are not observed.

Palatoquadrate and suspensorium. Most of the palatoquadrate and suspensorium is hidden by bones or the bones are broken so that a description is not possible. A small section of the entopterygoid (Fig. 4) is observed below the parasphenoid. No teeth have been observed in this region.

Opercular - branchiostegal series, and gular plate. A description of the opercular bones cannot be provided due to the extent of damage of this region, but a restoration of the opercular region (Figs 4, 5) reveals that all of these bones were narrow and elongated, an assumption based on the narrow space left between the orbital region and the cleithrum. It is accepted here that the interopercle was remote from the lower jaw based on the position of the last branchiostegal rays and the opercular bones (Fig. 5). According to the preserved fragments, the opercle (Fig. 4) has a rounded dorsal margin (preserved in medial view of right opercle) and posteriorly extends on the narrow cleithrum, reaching the lateral surface of the dorsal postcleithrum. Three branchiostegal rays are preserved displaced above the posterior part of the lower jaw and between the opercular region and the cleithrum/clavicle. They are elongate and narrow distally. A fragment lying between the angular and the clavicle may be part of another branchiostegal. There is no evidence of a gular plate.

Vertebral column and intermuscular bones. The vertebral column (Figs 2, 3, 6) is represented by the space occupied by the notochord that narrows caudally separating the epaxial and hypaxial regions, a series of ossified dorsal arcocentra, neural arches and their spines, and ribs and haemal arches and their spines ventral of the notochord. The vertebral column includes about 30 vertebral segments with the exception of the ural region. The abdominal centra, although not well preserved, are represented by thin narrow well-ossified dorsal arcocentra that extend ventrally forming most of the centra. It is unclear if the arcocentra surround chordacentra or not. The neural spines are also narrow, short, not reaching the ventral tip of the dorsal pterygiophores and they are inclined posteriorly, except for the most anterior spines. There is a series of thin and very short ribs preserved (Figs 2, 3). The caudal vertebrae bear neural spines longer and stronger than those of the abdominal region. The strongly ossified dorsal arcocentra are well developed and extend ventrally forming most of the lateral surface of the centra in the caudal region, and they are comparatively larger than those of the abdominal region. Some haemal spines are displaced showing both sides of the arch (Fig. 6). The posterior dorsal arcocentra of the caudal region are narrower than the ventral arcocentra. The caudal vertebrae bear single neural spines, whereas the neural spines are paired in the abdominal region. There are remnants of seven narrow, thin supraneurals (Figs 2, 3) positioned between the posterior margin of the braincase and the first dorsal pterygiophore. No other intermuscular bones have been observed.

Paired fins. A small supracleithrum (Fig. 4) is present dorsal to the dorsal tips of the cleithrum and dorsal postcleithrum. The cleithrum is an elongate, narrow, deep bone, with a deep dorsal limb and with a slight curvature ventrally. A long, vertically-oriented region characterized by its corrugated surface is observed where the anterior margin of the bone is exposed. An elongate, slightly triangular bone articulates with the antero-ventral margin of the cleithrum. This element is interpreted as a clavicle because of its position (see Comparison and Discussion). A most remarkable feature of the fish is the presence of two large and expanded postcleithra. The dorsal postcleithrum, which reaches almost to the dorsal tip of the cleithrum, is approximately half of the depth of the cleithrum. The dorsal postcleithrum joins the ventral one through an oblique overlap. The ventral postcleithrum is slightly ovalshaped and narrows ventrally. Both postcleithra have a close relationship with the cleithrum forming a compact bony series just behind the opercular region. The pectoral fins (Figs 2, 3) have a low position on the flanks, closer to the ventral margin of the body than to the middle flank. The fins are long, extending posteriorly over the origin of the pelvic fins. There are 15 or 16 pectoral rays preserved, the anterior most are broken. The pectoral rays are characterized by the presence of long bases; they are branched distally. Due to condition of preservation it is unclear whether the rays are segmented distally or not. The pelvic bones or basipterygia are incompletely preserved, but the most complete one is slightly club-shaped, narrowing at it middle length and slightly expanding anteriorly. The pelvic fins (Figs 2,3) reach posteriorly to the middle of the length of the anal fin rays. There are seven or eight pelvic rays and one splint preserved in one fin and three incomplete rays in the other fin. The pelvic rays are long 
based and are segmented and branched at their most distal region. Fringing fulcra have not been observed associated with the leading margins of the pectoral and pelvic fins.

Dorsal and anal fins. The long-based dorsal fin (Figs 2, 3 ) is positioned slightly behind the half of the standard length, slightly anterior to the origin of the pelvic fins. It occupies $39 \%$ of the dorsal midline between skull roof and start of the caudal fin. The insertion of its most posterior ray is positioned posterior to the insertion of the last anal ray. The dorsal margin of the fin seems to be gently rounded. The dorsal fin (Figs 2, 3) is supported by thin and elongate proximal radials; the presence of medial and distal radials is unclear. Nineteen proximal radials are preserved. There are 19 rays articulating with the pterygiophores. There is one small element in front of the fin. It is unclear if this is a small precurrent ray or a basal fulcrum. The first small element is followed by one moderately long, unsegmented-and-unbranched ray, which articulates with the first rod-like proximal radial. The next ray is long and segmented. All following rays are segmented and possibly branched (the rays are partially damaged) and at least the last ones show distal branching and segmentation. All pterygiophores support one ray, except for the last one supporting two rays. The anal fin (Figs 2, 3) is short-based with only three preserved proximal pterygiophores and 10 or 11 rays. The thin rays are long, extending below of about half the length to the caudal fin. The rays have long bases and are segmented and branched at their distal tips. Fringing fulcra have not been observed associated with the leading margins of both the dorsal and anal fins.

Caudal fin. The caudal fin (Figs 2, 3, 6) is lacking the posterior tips of the rays. In addition, some portions of the endoskeleton are damaged. However, the preserved rays and endoskeletal structures indicate the presence of a heterocercal tail with a notochord almost reaching the dorsal margin of the fin, a small dorsal lobe composed by basal fulcra, and a ventral lobe forming most of the tail. Because of the preserved rays, it is possible to assume that the tail was not bifurcated distally. Five preural and at least four ural vertebrae (Fig. 6) support the basal fulcra and rays. The centra of the preural vertebrae are incompletely preserved, but the preserved elements confirm the presence of well developed and ossified dorsal arcocentra that extend ventrally and form an arcocentral type of centrum together with the expanded, well ossified ventral arcocentra. This arcocentral-type centrum can be easily observed at least from preural vertebrae 7 to ural vertebra 1 (Fig. 6). Although the ventral arcocentra of preural vertebrae 5 to 1 are partially broken, they are broadly expanded. The smallest of all of them is the ventral arcocentrum of preural centrum 1 .

The neural spines of preural vertebrae 4 to 1 are slightly broader than most anterior spines and inclined towards the vertebral axis. Neural spines of preural ver- tebrae 3-1 are slightly expanded distally. Neural spine of ural vertebra 1 seems to be shorter than preceding spines, but also it is expanded distally. There are three elongate neural spines (with their arches destroyed) that would correspond to ural vertebrae $2-4$. It is possible that more elements are present but the dorsal part of the ural region is partially destroyed. Five elongate epurals (Fig. 6) are present. Two are observed at the level of the neural spine of preural vertebrae 2 and above the neural spine of preural vertebrae 1, and three epurals above the ural region. The fifth element is interpreted as an epural because its position at the same level of the anterior epurals.

The haemal spines of preural vertebrae 4 to 1 (Fig. 6) are more expanded than those of anterior caudal vertebrae. The haemal spine of preural vertebra 1 or parhypural is narrower than the haemal spine 2 . The arcocentra of all these spines are broadly expanded, even that of the parhypural that is partially damaged. The proximal regions of the hypurals are not related to any chordacentra. There are six hypurals preserved but more hypurals were present because of the remnants observed between the proximal region of the first hypaxial long rays. The size of hypurals decrease slightly caudally. No diastema is observed between hypurals 2 and 3.

There is one elongate element placed anterior to the basal fulcra of the dorsal lobe, which is interpreted here as the dorsal caudal scute. Three elongate epaxial basal fulcra are observed. Based on the position and length of the last fulcrum, no more basal fulcra are expected. There are 19 hypaxial long rays, which are preceded dorsally by one shorter ray. It is unclear if the latter is a rudimentary ray. There are five shorter ventral elements that are interpreted as hypaxial basal fulcra. The middle long hypaxial rays are distally segmented and branched. However, it is important to note that the rays have long bases and show scarce segmentation probably due to the fact that their external surfaces are damaged. We assume that the tail was slightly rounded based on the preserved fin rays. Urodermals and fringing fulcra have not been observed.

Scales. No scales are preserved on the body, but a few large, slightly square or rectangular-shaped scales are displaced above the caudal peduncle. The scales are preserved in inner view so that it is not possible to provide information if they have ornamentation or not or if they are ganoid or amioid-like scales (sensu Schultze 1966, 1996). Remnants of scales are displaced on the caudal fin rays.

\section{Comparison, discussion, and conclusion}

\section{Possible ontogenetic age of the studied specimen}

Defining developmental stages in fishes is difficult even in Recent fishes. The limits are fluent, and the features of the different levels of fishes are so different 
that there is no agreement in defining different developmental stages in Recent fishes (e.g., Webb 1999; Urho 2002). Variation of developmental forms in Recent fishes is so large that in many cases it is difficult to separate larvae from juveniles and adults. The larval stage is characterized by yolk sac and fin-fold (first oral feeding) in fishes with indirect development; metamorphosis marks the end of the larval stage in indirect development and the beginning of the juvenile stage. In fishes with direct development a larval stage is difficult to define. The juvenile stage is characterized by allometric growth and completion of scale cover. After Balon (1999, p. 30), "A juvenile is the beginning of a definitive phenotype in which most of the embryonic and larval temporary structures degenerated and most vital permanent adult organs or structures are formed."

Macrosemiiforms include small to moderate long species ranging from $32 \mathrm{~mm}$ (Enchelyolepis pectoralis; Woodward 1918; H.-P. Schultze personal observation) to $220 \mathrm{~mm}$ length (Histionotus oberndorferi). Thus, Voelklichthys comitatus n. gen. n. sp., with its approximately $30 \mathrm{~mm}$ total length is the smallest known macrosemiiform.

The here described specimen of Voelklichthys is small in size and possesses a large head (43\% of SL) and large orbits ( $40 \%$ of head length) that may indicate that the fish is in an early stage of allometric growth. These can be juvenile features like the absence of scales on the body. However, the last feature is an artifact of preservation (see above). On the other side the ossification of the skull bones, especially of the lateral cranial orbital margin and of the vertebral elements such as the dorsal arcocentra in the caudal vertebrae and of the fin rays may indicate a subadult or even adult stage, a hypothesis that can be tested when more specimens are available.

The other small macrosemiid, Enchelyolepis, presents also a large head (Woodward 1918; Bartram 1977a), a feature that may be interpreted as belonging to an early stage of growth. However, the degree of ossification of different bones in the new fish as well as in Enchelyolepis gives contrary evidence. We believe that with only one specimen we cannot solve this problem, and for the moment we interpret the available specimen as a small-sized subadult or adult, based on bone ossification.

\section{Some remarkable morphological features}

Searching for information that could help us to assign Voelklichthys within a fish family or order, we noticed some features that are perhaps significant to be consid- ered in future studies of Voelklichthys n. gen. as well as other macrosemiiforms and neopterygians.

Body Shape. Most macrosemiiforms have a fusiform or slightly elongate body (Figs 7A, B, F). However, some of them may be slightly oblong such as Propterus elongatus and P. microstomus (Figs 7C, D) and Uarbryichthys (Fig. 8G), but not as oblong as Voelklichthys (Figs 2, 3, 8H). The body of Enchelyolepis tapers from the occiput backwards (Bartram 1977a). So far it is known, the body shape of Voelklichthys is unique within macrosemiiforms.

Premaxillary and dentary teeth. Voelklichthys bears tiny teeth in both the premaxilla and dentary (Fig. 4). Each preserved premaxillary tooth has an elongate base of similar diameter ending in a small conical tip. In contrast, the dentary teeth are smaller than the premaxillary teeth, but there is not a clear distinction between the base and the tip of each tooth. This feature is not associated with the small size of the specimen because small specimens of Notagogus, as small as Voelklichthys, bear already the large teeth that characterize this genus as well as other macrosemiids (Fig. 9). The teeth in Enchelyolepis are described as "much elongated" (Woodward 1918, p. 80) and "closely set and pointed" (Bartram 1977a, p. 166). Dentary and premaxillary teeth are still unknown in Uarbryichthys. Dentary and premaxillary teeth are commonly large, robust and conical in shape in macrosemiids. To our best knowledge, no other macrosemiiform seems to have such small teeth on the premaxilla and dentary as those present in Voelklichthys.

Vertebral centra. The vertebral column is unknown in most macrosemiiforms due to the preservation of the whole body squamation in most recovered specimens. According to Bartram (1977a, p. 215) "monospondylic ring centra are present in the abdominal region of Macrosemius, Histionotus and Enchelyolepis. These centra are thick, constrict the notochord and fuse with the arches; their greater part is composed of perichordal, endochondral bone. Although the anterior vertebrae of Notagogus form rings, they separate into dorsal and ventral crescents. Whether they are mainly chordacentral or not it is difficult to assess. In Propterus elegans, centra are formed only in the first few segments; they consist of dorsal crescent alone, and are probably chordacentral." To the best of our knowledge, there is no endochondral component in the vertebral centra of the Late Jurassic macrosemiids of the Solnhofen limestones, including at least Propterus, Notagogus, Histionotus, and Voelklichthys. Additionally, there is no evi-

Figure 7. Macrosemiiform fishes in lateral view (slightly modified from Bartram 1977a). A. Macrosemius rostratus (Eichstätt, Kelheim, Bavaria, Germany; lower Tithonian); B. Legnonotus krambergeri (Hallein, Austria; Upper Triassic); C. Propterus elongatus (Eichstätt, Bavaria, Germany; lower Tithonian); D. Propterus microstomus (Eichstätt, Kelheim, Bavaria, Germany; lower Tithonian); E. Histionotus oberndorferi (Kelheim, Bavaria, Germany; lower Tithonian); F. Notagogus denticulatus (Eichstätt, Kelheim, Bavaria, Germany; lower Tithonian). 

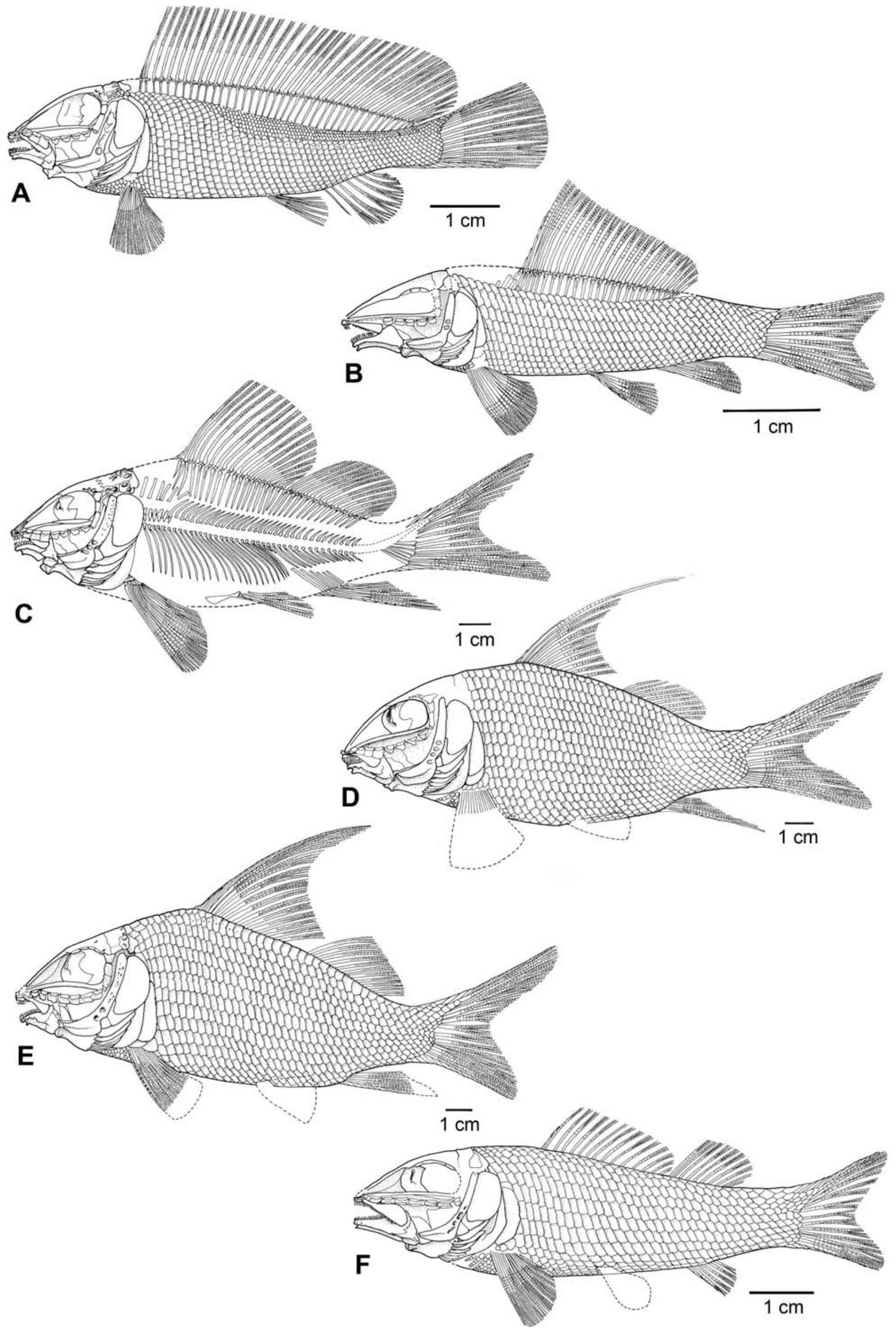

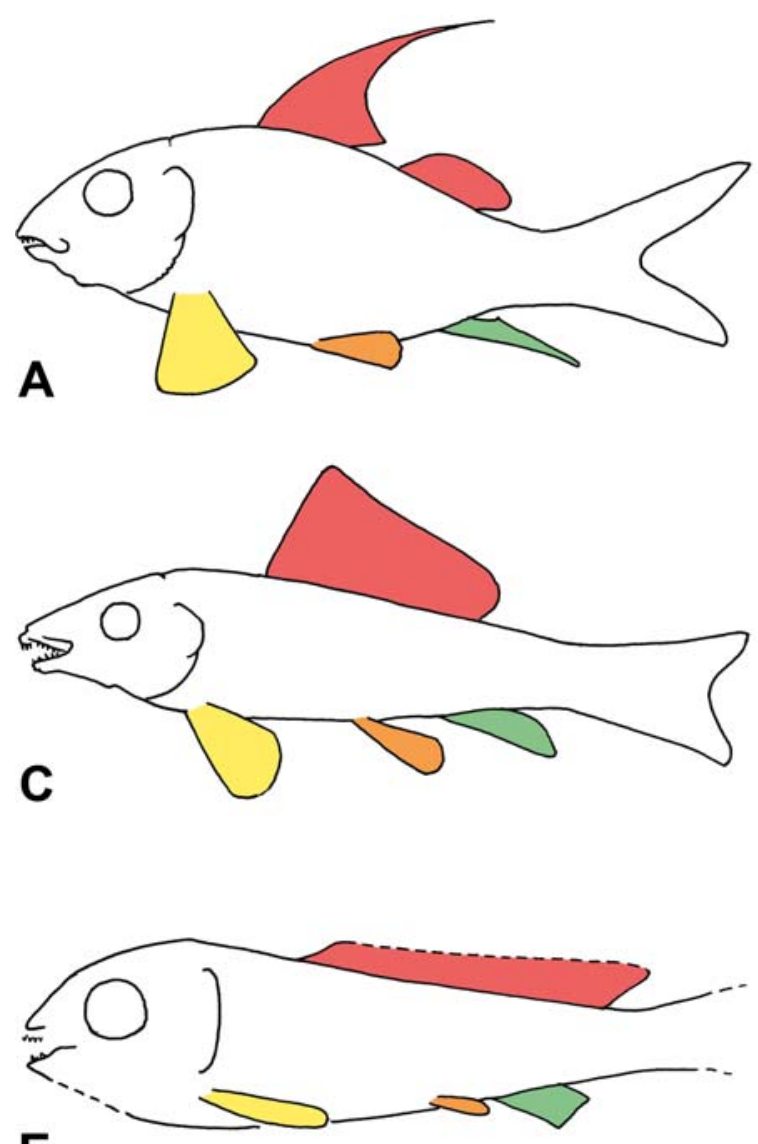

E

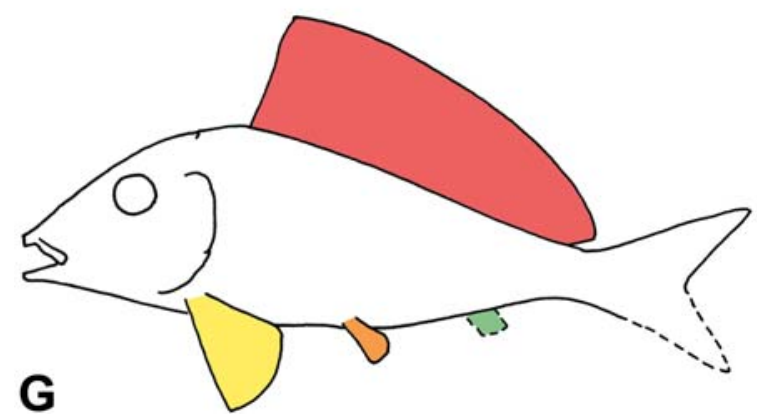

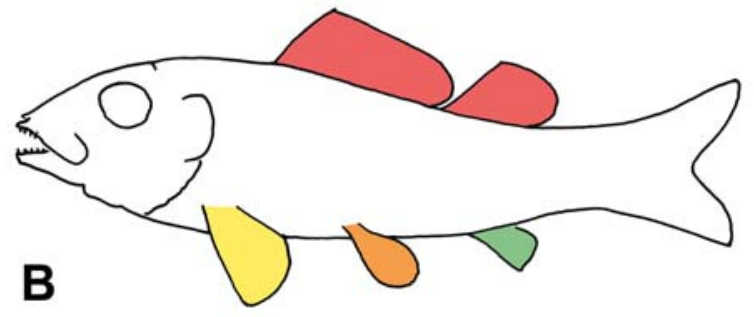
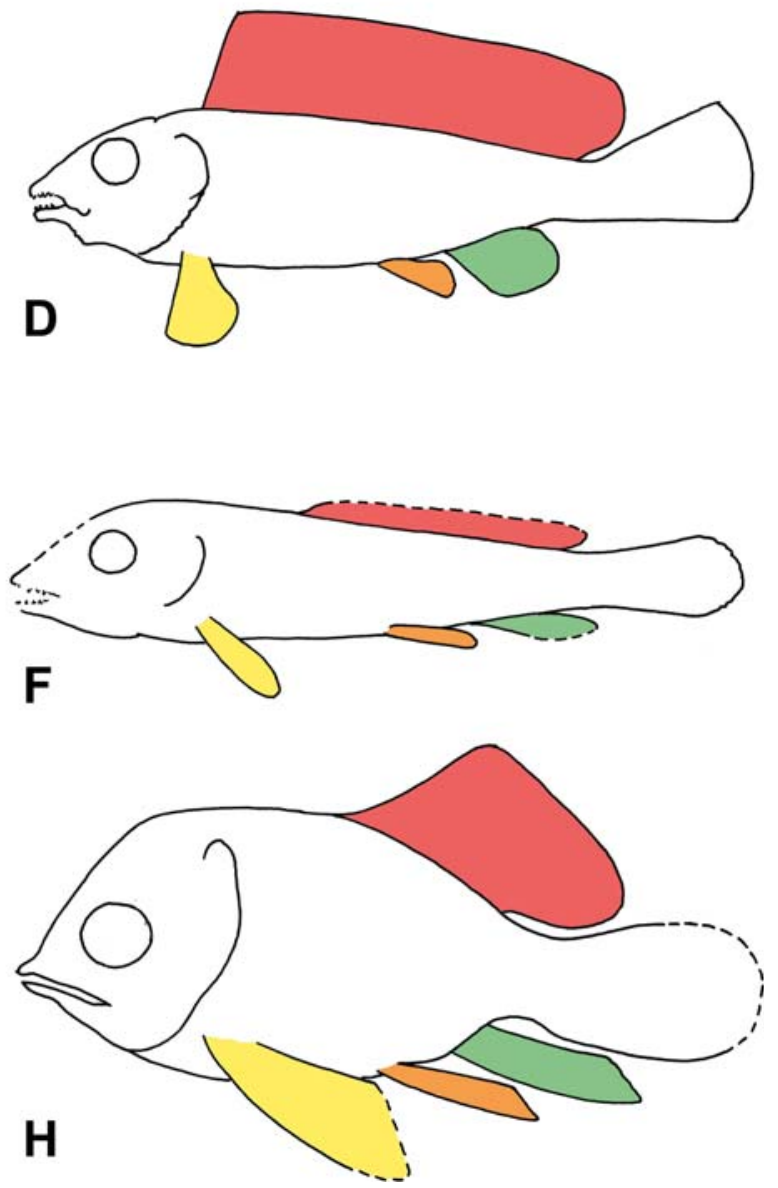

Figure 8. Diagrammatic reconstruction of the overall shape of body and fins of macrosemiiform fishes in lateral view illustrating differences in shape, length, and number. A. Propterus microstomus; B. Notagogus denticulatus; C. Legnonotus krambergeri; D. Macrosemius rostratus; E. Enchelyolepis andrewsi (BMNH P6303); F. Enchelyolepis pectoralis (BMNH P7359); G. Uarbryichthys latus (AM F43258); H. Voelklichthys comitatus n. gen. n. sp. Pectoral fins are shown in yellow; pelvic fins in orange; dorsal fins in red; and anal fins in green.

dence, at least in these genera, that the centra constrict the notochord. The morphology of the vertebral centra of Voelklichthys differs from the description given for Enchelyolepis by Bartram (1977a) for the caudal vertebrae (see below discussion of the caudal skeleton).

Voelklichthys gives a different scenario to Bartram's (1977a) statements. In this fish the centra are mainly formed by the dorsal arcocentra (that ossify perichondrally in all fishes we have studied the development; e.g., Schultze \& Arratia 1986, 1988; Arratia \& Schultze 1992; Arratia et al. 2001). The perichondral ossification extends laterally and ventrally forming most of the lateral wall of the centra (Figs 2, 3, 6). In the abdominal region, the lateral wall seems to be incompletely ventrally, but the centra are mainly formed by the elongate narrow dorsal arcocentra, whereas in the caudal region the lateral wall is mainly formed by the dorsal arcocentra and by the antero-posteriorly expanded ventral arcocentra.

Vertebrae of arcocentral type are also found in fishes such as aspidorhynchiforms and some Late Jurassic "pholidophoriforms" with an arcocentral perichondral ossification surrounding the chordacentrum. The bony centrum is not an autocentrum, but the result of the lateral growth of the dorsal and ventral arcocentra, which 


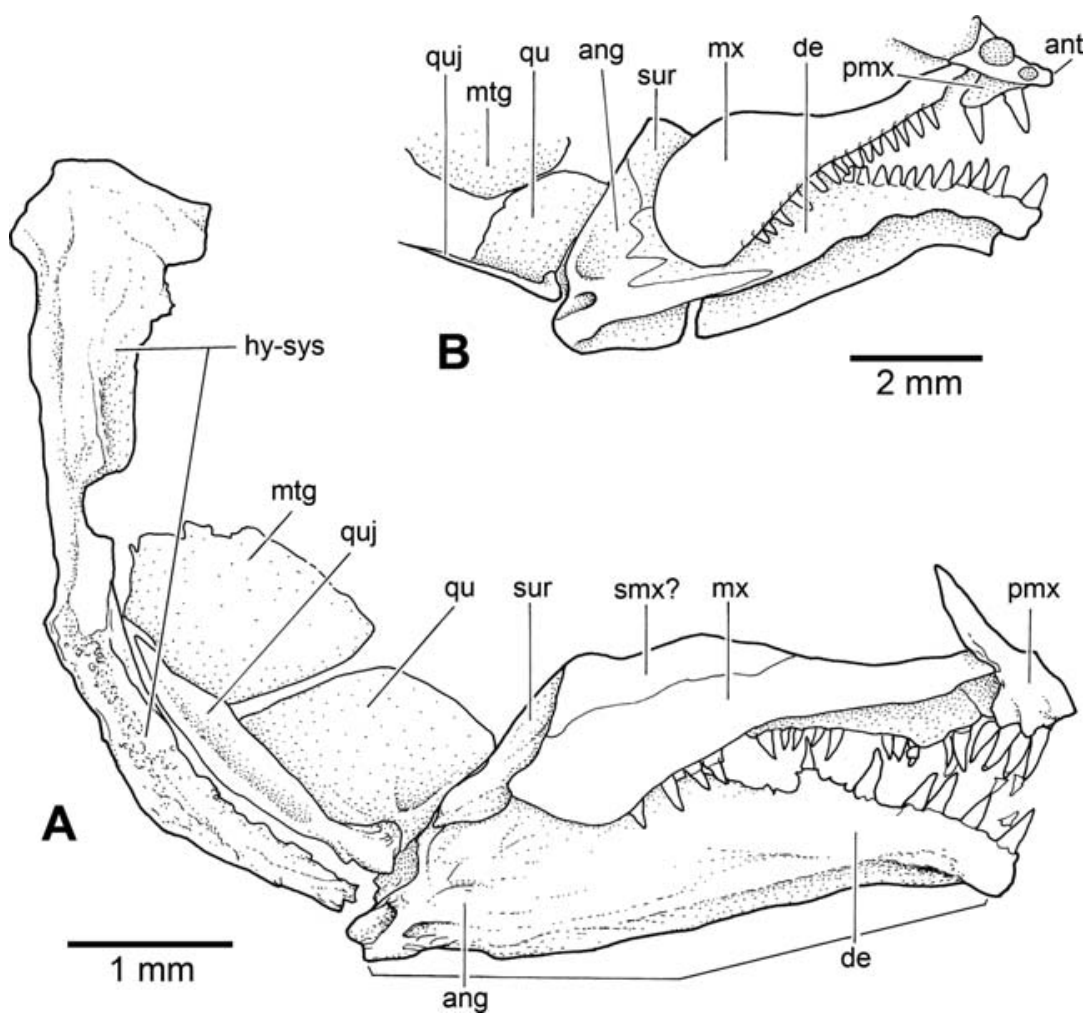

Figure 9. A. Part of the suspensorium and jaws in lateral view of a young specimen of Notagogus sp. from Ettling, Late Jurassic, Solnhofen Plattenkalk (JME ETT $843 ; 29.72 \mathrm{~mm}$ total length). The suture between angular and dentary was not observed due to the thin ossification of parts of the jaw; B. Notagogus denticulatus (BMNH P1090; slightly modified from Bartram 1977a, fig. 38). Abbreviations: ang - angular; ant - antorbital; de dentary; hy-sys - hyo-symplectic cartilage partially ossified; lj - lower jaw; mtg metapterygoid; mx - maxilla; pmx premaxilla; qu - quadrate; quj - quadratojugal; sur -surangular; smax? - supramaxilla? join laterally producing a compact arcocentral vertebra (Arratia 1997, p. 124; Arratia et al. 2001, p. 146-147). The arcocentral centrum is the result of fusion of both dorsal and ventral arcocentra in some "pholidophoriforms" (e.g., Siemensichthys macrocephalus). The condition in Voelklichthys n. gen. seems to be different because the main element of the centrum is the dorsal arcocentrum. It is unclear whether chordacentra are also present in Voelklichthys, and whether they are laterally covered by the arcocentra. Among extant actinopterygians, the centra begin to form as dorsal chordacentra in the middle sheath of the notochord in Lepisosteus (Schultze \& Arratia 1986; Arratia et al. 2001), and during growth the chordacentra become enclosed by perichordal ossifications. According to the available information this seems to be a unique character for lepisosteids. However, considering the incomplete knowledge about formation and structure of vertebral centra in basal neopterygians, this should be another point where more extensive research should be done just to understand the different patterns involved in the formation of vertebrae and their systematic and phylogenetic importance among basal neopterygians, including macrosemiiforms (which exhibit an outstanding morphological diversity in the structure of vertebral centra).

One diagnostic character of the Macrosemiidae is the presence of paired neural spines in the caudal region (Bartram 1977a); however, the presence of this feature among macrosemiiforms, as well other basal neopterygians, needs to be investigated further. The primitive actinopterygian condition is the presence of paired spines in the caudal region, and paired neural spines have been reported in Enchelyolepis and Propterus (Bartram 1977a) among macrosemiids, Lepisosteus (Schultze \& Arratia 1986; Grande 2010), and a few other actinopterygians (see Arratia et al. 2001, p. 149). In contrast, unpaired neural spines in the caudal region (Fig. 6) are present in Voelklichthys.

Pectoral girdle. The enlargement of the postcleithral region (Fig. 4), especially the ventral postcleithrum, seems to be unique to Voelklichthys. Large postcleithra, not as large as in the new fish, are also found in other macrosemiiforms where the bones are known. It is important to note that the description of postcleithra have been largely ignored in the literature although the bones are illustrated in some of the restorations (e.g., SaintSeine 1949, fig. 85b; Bartram 1977a, figs 1, 31, 37; Gonzalez-Rodríguez \& Reynoso 2004, fig. 2). According to the available information, the number of postcleithra seems to be variable in macrosemiiforms. For instance, only one small postcleithrum has been reported in Macrosemiocotzus americanus (González-Rodríguez et al. 2004, fig. 3). One dorsal postcleithrum and a series of smaller, scale-like postcleithra are found in Histionotus (Fig. 7E) and Notagogus (Fig. 7F; see Notagogus helenae in Saint-Seine 1949, fig. 85b). Two postcleithra, a large dorsal and a small ventral one, are known in Macrosemius (Fig. 7A) and Voelklichthys (Fig. 4). Two postcleithra, a dorsal and a ventral one, plus a series of scale-like additional postcleithra are present in Propterus (Figs 7C, D). Thus, a significant variety of postcleithral conditions is found in macrosemiiforms and needs further investigations to be properly understood. 
Previous descriptions of the pectoral girdle of macrosemiids present a bone articulating with the anteroventral portion of the cleithrum that was interpreted as a clavicle. For instance, a clavicle has been reported and illustrated in Histionotus (e.g., Woodward 1918, pl. XVII, fig. 1) and Enchelyolepis "with a stout clavicle" (Woodward 1918, p. 11). The element described and illustrated by Woodward (1918) as a clavicle, is also present in Voelklichthys (Fig. 4, cla), and it is interpreted here as a possible clavicle until future studies in more specimens will clarify this identification. According to Bartram (1977a, p. 221), following Patterson's (1973) neopterygian characters, macrosemiids have reduced clavicles, but "reduced" clavicles may be interpreted as very small clavicles or absence of them. However, most of Bartram's illustrations show incomplete pectoral girdles and with the exception of the ventral part of the cleithrum of Propterus elongatus (Bartram 1977a, fig. 27), there is no other detailed information. It is important to note that the antero-ventral margin of the illustrated cleithrum of P. elongatus is truncated anteriorly, suggesting the presence of another bone placed anteriorly. Consequently, we suggest to give a careful examination to the antero-ventral part of the cleithrum in future studies on macrosemiiforms, to clarify if a clavicle is present or not.

Fin rays. Paired, dorsal and anal fins are long in Voelklichthys, and are comparatively longer than in any other macrosemiiform (Fig. 8). Propterus elongatus (Fig. 7C) has long pectoral fins extending slightly over the origin of the pelvic fins and the anal fin extends below the first third of the tail. In Macrosemius rostratus (Fig. 7A) the dorsal fin rays reach the beginning of the tail. Thus, some macrosemiiforms may have one or other fin with long rays, but apparently, Voelklichthys is unique in having all fins with long rays (Fig. 3). While macrosemiiforms seem to have rays with relative long bases and many short segments forming each ray, Voelklichthys has also long bases and the segments seem to be larger than those in other macrosemiiforms and distally positioned (compare Figures 3 and 7).

Dorsal fin. In macrosemiiforms the origin of the dorsal fin is closer to the occiput that to the middle of the standard length (Figs 7A-F, 8A-G). In contrast, the dorsal fin is placed slightly behind the half of the standard length (Fig. 8H) in Voelklichthys, a character, which is here interpreted as unique among macrosemiiforms.

The dorsal fin in macrosemiiforms is usually long, and it may be divided (Figs 7C-F, 8A, B). The dorsal fin is undivided in Voelklichthys and Enchelyolepis, Macrosemius, Legnonotus, Agoultichthys, and Uarbryichthys (Figs 7A, B, 8C-H).

Enchelyolepis has about 25 fin rays articulating with stout pterygiophores (a diagnostic character of Enchelyolepis; Woodward 1918, p. 80). A similar number of dorsal fin rays are found in Legnonotus krambergari, Histionotus angularis, Notagogus helenae (25-27).
Twenty to 22 dorsal fin rays are present in Propterus scacchi and 22 to 25 in Notagogus denticulatus. Twenty to 27 rays are found in Propterus microstomus and Notagogus helenae. A higher number of dorsal fin rays is found in Propterus elongatus (28-32), Macrosemiocotzus americanus (30-32), Macrosemius rostratus (32-39), Uarbryichthys (40), and Agoultichthys chattertoni (47). Voelklichthys has 19 rays plus one additional element that may be a basal fulcrum or small simple procurrent ray (Fig. 3) articulating with narrow, thin pterygiophores; such a count seems to be the lowest number among the broad array of variation presented by macrosemiiforms (counts are from Woodward 1895 , 1918; Bartram 1977a; González-Rodríguez \& Reynoso 2004; González-Rodríguez et al. 2004; Murray \& Wilson 2009; personal observations).

Caudal endoskeleton and fin. The caudal skeleton of macrosemiiforms is apparently known only from two specimens, Enchelyolepis pectoralis (Fig. 10; Bartram 1977a, fig. 21) and Voelklichthys (Fig. 6). The knowledge of Enchelyolepis pectoralis is largely based on the impression of caudal elements of the holotype and only known specimen deposited at the Natural History $\mathrm{Mu}-$ seum London (BMNH P7539).

The interpretation of the neural and haemal arches and last vertebral caudal centra of Enchelyolepis pectoralis is that the centra constrict the notochord, fuse to the arches and are mainly formed by endochondral bone (Bartram 1977a, p. 215). However, the impression of the fish studied by Bartram (Fig. 10) does not provide any information concerning the type of bone forming the centra or about the constriction of the notochord due to the fact that the bones are missing and only their right lateral imprint is left. It could be the case that the fish has a similar kind of vertebral centra

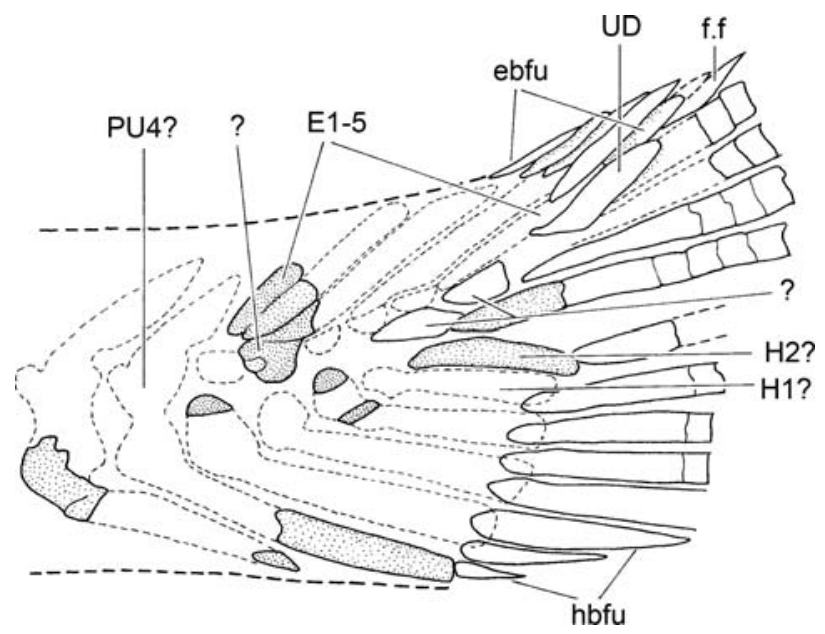

Figure 10. Caudal skeleton in lateral view of Enchelyolepis pectoralis (BMNH P7359; modified from Bartram 1977a, fig. 21). Abbreviations: ebfu - epaxial basal fulcra; E1-5 epurals $1-5$; numbering does not imply homology; f.f - fringing fulcra; H1, 2 - hypural 1, 2; hbfu - hypaxial basal fulcra; PU4? - preural vertebra 4?; UD - urodermal; ? - unidentified structure. 
as Voelklichthys but we cannot make assumptions on this. The division between preural and ural regions is unclear so that we are unable to agree or disagree with the identification of the first hypural and of preural centrum 5 in Enchelyolepis and prefer to identify them with question marks in Figure 10. At least six hypurals are preserved in Voelklichthys, any of which is associated to a ventral chordacentra, a situation also present in lepisosteids (Schultze \& Arratia 1986, 1989, figs 16, 17; Grande 2010). It is expected that many more hypurals were present in Voelklichthys.

The neural spines of the last caudal vertebrae including preural vertebrae 5 and 4 (and probably 3) bear long, narrow anterior processes at their proximal regions in Voelklichthys. The spines of preural vertebrae 5 to 1 are elongated and inclining closer to the vertebral axis progressively. The shortest spine is that of preural vertebra 1 . Remnants of neural arches and spines of ural vertebrae 1 to 4 are present in Voelklichthys. Although incompletely preserved, the caudal endoskeleton of Voelklichthys is more informative than that of Enchelyolepis (compare Figures 6 and 10).

One interesting aspect of the caudal skeleton of Enchelyolepis and Voelklichthys is the presence of five elongate bones identified as epurals (Figs 6, 10). In both genera the most anterior epurals are associated to the preural region and the most posterior with the ural region.

The caudal fin of Enchelyolepis pectoralis presents some elongate scales identified as urodermals (Bartram 1977a, fig. 21), but the position of the two most ventral ones is unlike that of urodermals in other fishes including macrosemiiforms, in which the urodermals are associated to the base(s) of the first principal ray(s) (Arratia 2008, figs 14, 15, 18; Fig. 11 herein).

The count of caudal fin rays seems to be taxonomically important in macrosemiids (Bartram 1977a; González-Rodríguez \& Reynoso 2004; González-Rodríguez et al. 2004; Murray \& Wilson 2009). However, it is unclear how the rays are counted because the numbers of rays illustrated in some restorations do not agree with numbers given in the text (see below). It is interesting to remark that macrosemiiforms seem to have one or two epaxial rudimentary rays (Figs 7D, 11; see also González-Rodríguez \& Reynoso 2004, fig. 5; Arratia 2008, fig. 15) dorsal to the first principal ray and such ray(s) is commonly not mentioned, but it is included in the total count in some cases. Arratia (2008; Fig. 11

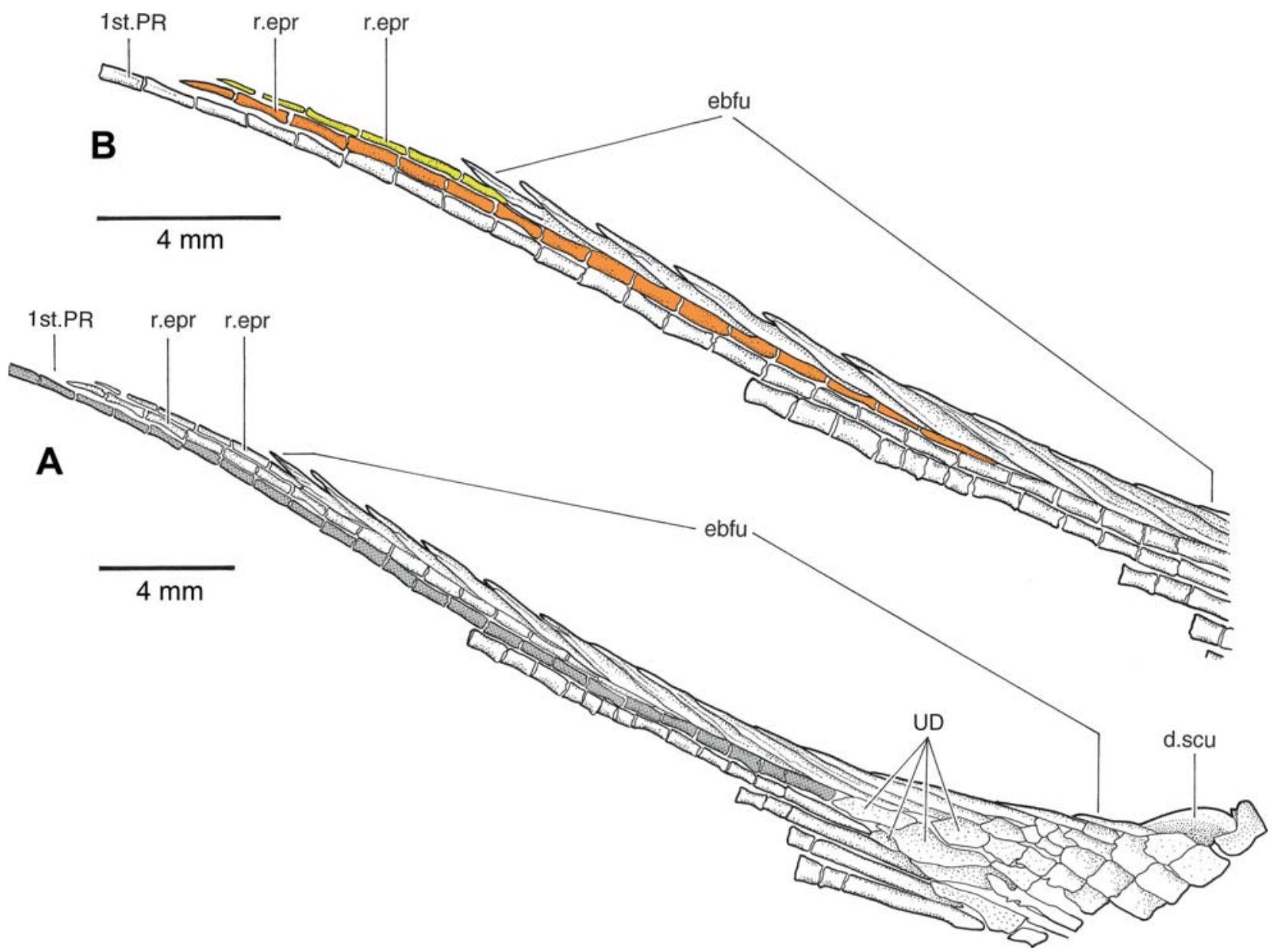

Figure 11. A. Dorsal part of the caudal fin of the macrosemiid Propterus microstomus (JME SOS 32496); B. Enlargement of a section in A to show some details of basal fulcra and rudimentary rays. Abbreviations: d.scu - dorsal scute; ebfu - epaxial basal fulcra; r.epr - rudimentary rays; UD - urodermals; 1st.PR - first principal ray. (after Arratia 2008). 
herein) illustrated two epaxial rudimentary rays in Propterus microstomus; however, the most dorsal ray in Propterus elongatus (Fig. 7C) is branched in Bartram's (1977a, fig. 31) illustration, but the position and structure of the most dorsal branch is that of the epaxial rudimentary ray in Propterus microstomus (Arratia 2008, fig. 15). The total number of principal rays in Voelklichthys is higher (19) than in other macrosemiiforms. In contrast, the other small macrosemiiform, Enchelyolepis pectoralis, has the lowest number (10).

Scales. The scales of macrosemiiforms vary depending from the body region as do scales in actinopterygians in general (Schultze 1966). In general, macrosemiids have rhombic scales (Fig. 12) with ganoine and the typical socket-and-peg articulation. Macrosemiids change from rhombic to round scales on the same fish. The change from rhombic to round or elasmoid scales appears in the antero-ventral part of the body, the mobile gular region, as demonstrated for Propterus microstomus by Schultze (1966, fig. 31). The round or elasmoid scales possess the radiating structure on the covered part of the scale, which is typical for amioid scales. Growth lines on the internal side of the scales, which occur also on rhombic scales, should not be confused with circuli present on the surface of cycloid scales of teleosts. Not only the shape of the scales changes, but also their structure. Typical rhombic ganoine scales change into amioid round scales without ganoine, but with a thin surface layer of bone and a basal layer of mineralized connective tissue.

Both species of Enchelyolepis have amioid round scales (Figs 12H, I; Schultze 1966, fig. 34) with ridges, which radiate from the growth centre on the covered field, and grooves on the free field. Similar round scales occur in the gular region of Macrosemius rostratus (Schultze 1966, p. 275), Notagogus pentlandi, N. denticulatus (Schultze 1966, figs 33a, b), and Propterus microstomus (Schultze 1966, fig. 31). Three small specimens between 3 and $5 \mathrm{~cm}$ total length of Notagogus pentlandi (Woodward 1895, p. 187) on one piece numbered BMNH P1097 (and studied by H.-P. Schultze), have the same kind of scales as the two Enchelyolepis species. Information about the scales of Voelklichthys is not available yet due to conditions of preservation, but the scales preserved in inner view are square-like and rectangular shaped. As above noted, the type of scales of macrosemiids may be different intraspecifically, always depending from the body region. This makes it necessary to study not only scales of the flank, but also those of the gular, dorsal and ventral regions of the body to understand the distribution of different types of scales in macrosemiiforms.

\section{Taxonomic assignment and possible relationships}

The small fish described herein is unique within the Solnhofen fishes. It does not resemble any fish described from the Solnhofen area nor from other Jurassic localities. With an incomplete antero-dorsal circumorbital ring, the narrow opercular region, and long dorsal fin, it resembles a macrosemiiform but missing most characters of the family Macrosemiidae, which is best known from the Jurassic macrosemiids of the Late Jurassic Solnhofen limestones.

Since Bartram (1977a) macrosemiids did not receive much attention until recently with new studies on these fishes. For instance, González-Rodríguez \& Reynoso (2004), González-Rodríguez et al. (2004), and Murray $\&$ Wilson (2009) described new genera of macrosemiids, whereas Grande (2010) and Cavin (2010) included macrosemiids in their phylogenetic analyses of holosteans and semionotiforms, respectively. The order Macrosemiiformes was introduced by Carroll (1988) and the name was used later by Nelson (2006), but diagnostic characters were not given. According to Grande's (2010) phylogenetic analysis of Holostei, the macrosemiiforms (represented by Macrosemius rostratus) are characterized by (1) an incomplete circumorbital ring (lateral edge of frontal [of traditional terminology] or nasal bones makes up part of orbital margin, or anterior part of ring absent); (2) supramaxilla absent; and (3) presence of coronoid tooth morphology of robust broadly or bluntly tipped teeth. Characters 1 and 2 (Fig. 4) are present in Voelklichthys. The new fish lacks a supramaxilla, and its antero-dorsal orbital margin is formed by the well-developed lateral margin of the parietal bone alone [ = frontal bone of Grande (2010)], so that the circumorbital ring is incomplete antero-dorsally. Supraorbital bones may be lacking in Macrosemius; nevertheless, they are present in Legnonotus, Propterus, Histionotus, Notagogus, and Macrosemiocotzus. The third character should be studied in more members of the group because the coronoid tooth morphology is unknown in many macrosemiiforms. Thus, Voelklichthys shares characters 1 and 2 with macrosemiiforms in Grande's (2010) characterization of the group. Still, we would like to point to the fact that the presence/absence of a supramaxilla should be studied in young specimens because while adult specimens of Notagogus from the Solnhofen limestones do not show a separate supramaxilla (Fig. 7F), a very well preserved, small specimen of Notagogus from Ettling (Bavaria, Germany), shows a separate element that we interpret as a possible supramaxilla (Fig. 9A). A comparison (Figs 9A, B) between the shape of the young and the adult maxilla gives the idea that the bone present in the adult is a composite bone result of the fusion of two, a feature that needs to be confirmed in other young individuals

According to our revision of the available literature as well as specimens, the content of the Macrosemiiformes seems to be problematic. Three groups are currently considered within the Macrosemiiformes: the Macrosemiidae Thiollière, 1858, the monotypic Australian Jurassic family Uarbryichthyidae Bartram, 1977a, and an unnamed clade [Aphanepygus + Placidichthys], that is the sister group of the Macrosemiidae 

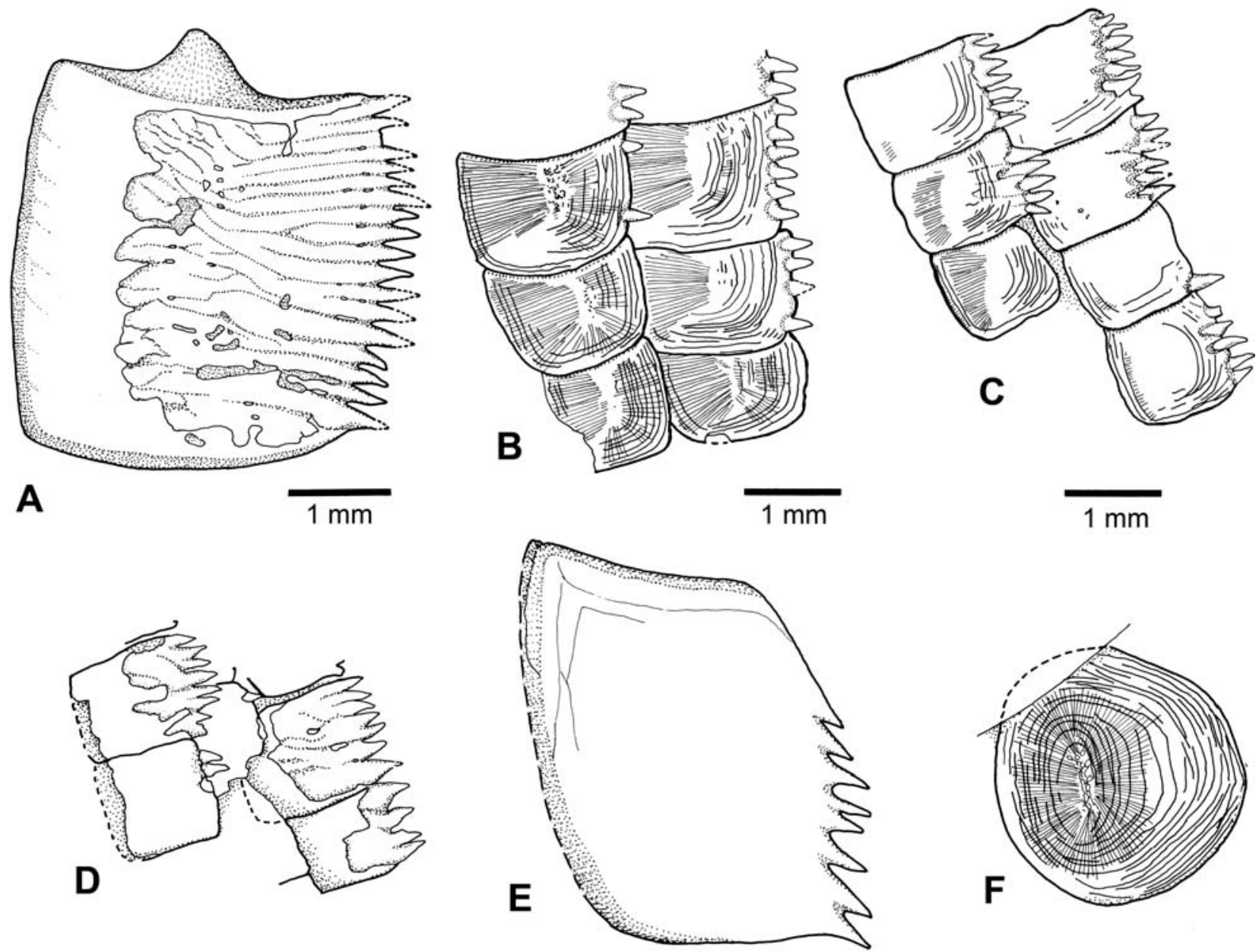

$1 \mathrm{~mm}$
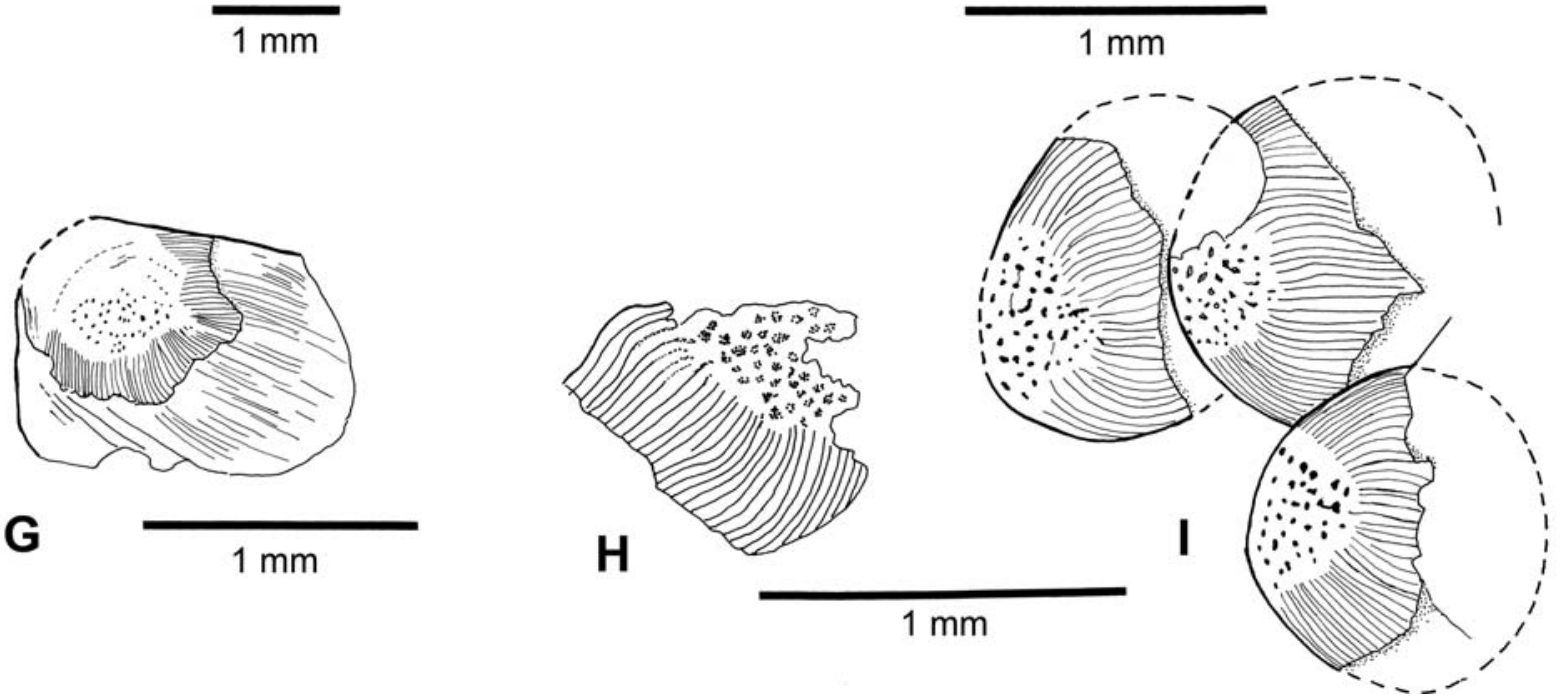

Figure 12. Rhombic (ganoid) and amioid scales of macrosemiids: A-D. Macrosemius rostratus. A. Scale of anterior body flank about 12th scale row behind head (specimen BSP AS.VI.24, Solnhofen, Late Jurassic, Solnhofen Plattenkalk); B-D. Specimen BMNH P7177, reversed, Eichstätt, Late Jurassic, Solnhofen Plattenkalk; B. Ventral scales in front of pelvic fin; C. Ventral scales in front of anal fin [6th scale row behind B]; D. Scales above anal fin [two scale rows behind C]; E-F. Notagogus denticulatus (specimen BMNH P3601, Kehlheim, Late Jurassic, Solnhofen Plattenkalk; same scale); E. Rhombic scale of posterior body flank; F. Amioid scales of the gular region. G. Notagogus pentlandi (BMNH P1097, Torre d'Orlando, Castellamare, Naples, Late Jurassic), amioid scale of the dorsal anterior body; H-I. Enchelyolepis pectoralis (BMNH P7359, Savonnières-en-Perthois, Mosel, Upper Jurassic; same scale), amioid scales from the posterior body flank. 
in the phylogenetic analysis by Murray \& Wilson (2009). The family Macrosemiidae was interpreted for a long time as an European Late Triassic to Early Cretaceous taxon known at least by six genera (Macrosemius, Legnonotus, Enchelyolepis, Propterus, Histionotus, and Notagogus) in the Upper Triassic - Late Jurassic strata of Europe (Figs 7A-F, 8A-F). Recently the geographic and temporal range of the family has been extended to include new forms outside Europe with Macrosemiocotzus and Notagogus novomundi from the Albian of Central Mexico (González-Rodríguez et al. 2004; González-Rodríguez \& Reynoso 2004) and Agoultichthys chattertoni from the Upper Cretaceous of Morocco (Murray \& Wilson 2009).

The Late Jurassic Australian family Uarbryichthyidae is known from two incompletely preserved specimens. Among characters are two extrascapulae that are excluded from the midline and carry the supratemporal commissure or extrascapular canal unlike macrosemiids. A posttemporal, also triangular shaped as the extrascapula, lies behind the latter bone (Fig. 13). The cephalic sensory canals are narrow and bony enclosed, unlikely in macrosemiids. A long, undivided dorsal fin extends along most of the dorsal margin of the body (Fig. 8G). Voelklichthys shares with Uarbryichthys the first two cranial characters. Although in both genera

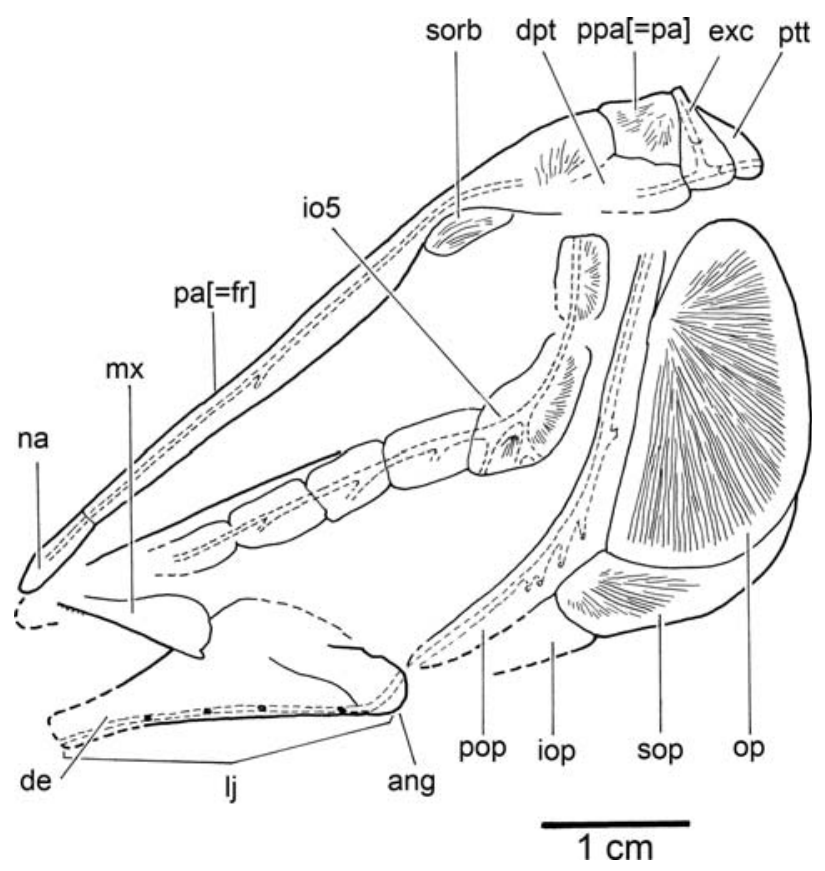

Figure 13. Uarbryichthys latus, Late Jurassic, Talbragar, New South Wales, Australia (slighly modified from Bartram 1977a; head reversed to the left). Restoration of the head in lateral view. Abbreviations: ang - angular; de - dentary; dpt - dermopterotic; exc - extrascapula; io5 - infraorbital bone 5; iop - interopercle; lj - lower jaw; mx - maxilla; na - nasal bone; op - opercle; $\mathbf{p a}[\mathbf{=} \mathbf{f r}]-$ parietal bone $[=$ frontal bone of traditional terminology $]$; ppa[= pa] - postparietal bone [= parietal bone of traditional terminology]; $\mathbf{m x}$ - maxilla; pmx - premaxilla; pop - preopercle; ptt - posttemporal bone; r.op right opercle; sop - subopercle; sorb - supraorbital bone. the sensory canals are bony enclosed, those in Voelklichthys are comparatively broader than in Uarbryichthys. Despite these similarities, there are some major morphological differences between Voelklichthys and Uarbryichthys as for instance: Both fishes have an undivided dorsal fin (a presumable plesiomorphic character), but that of Voelklichthys is not as long as that in Uarbryichthys (compare Figures 2, 3 and 8G); the shape of the head and of the lower jaw (compare Figures 4 and 13); the presence of one supraorbital bone in Uarbryichthys, but absent in Voelklichthys; the lengths of the paired fins that are long in Voelklichthys and short in Uarbryichthys (compare Figures 3, $8 \mathrm{H}$ and $8 \mathrm{G}$ ); and the presence of ganoine ridges on certain cranial bones, postcleithra, and scales in Uarbryichthys that it seems to be a unique character for this genus.

The group formed by Aphanepygus (Bartram 1977b) and Placidichthys (Brito 2000) appears as sister group of macrosemiids in the cladogram by Murray \& Wilson (2009, fig. 8) placing Uarbryichthys as the sister group of $[[$ Aphanepygus + Placidichthys $]+$ Macrosemiidae $]$. However, as the authors recognized, this sister group relationship is not strongly supported. The Late Cretaceous Aphanepygus is a European genus with an elongated body bearing two dorsal fins and six extrascapulae, which carry the supratemporal commissure or extrascapular canal (Bartram 1977b). It has an unusual bone, an elongated median bone anterior to the parietals named as "anterior frontal" by Bartram, two rows of supraorbital bones, and four infraorbitals overlapped by scales, which cover the cheek region. The division of the dorsal fin is the one feature common with macrosemiids. Bartram (1977b, p. 369) interpreted this genus as not belonging within the Macrosemiidae, but closely related to it.

Placidichthys was placed within the Ionoscopiformes by Brito (2000) and Brito \& Alvarado-Ortega (2008). They excluded Placidichthys from the Macrosemiidae on the differences in number and shape of the infraorbitals, shape and position of jaws, the presence of gulars, and the lack of a quadratojugal. The genus possesses a pair of extrascapulae, which carry the supratemporal commissure. Placidichthys and Aphanepygus have in common with macrosemiids an elongated body, absence of teeth or presence of small teeth on the maxilla, and a divided dorsal fin (like in some macrosemiids).

Two main features characterize macrosemiids according to Bartram (1977a): (1) nine scroll-like infraorbitals bones, two placed behind the orbit and (2) the interopercle remote from the mandible. Two other features were added by Murray \& Wilson (2009): (3) dorsal fin long, may be divided, and (4) jaw articulation placed in front of the orbit. Character 1, as far as the preservation permits, is not present in Enchelyolepis and Voelklichthys. Character 2, an interopercle remote from the lower jaw, is present in Voelklichthys (Fig. 5). Voelklichthys has a long dorsal fin (character 3), not as long as in macrosemiids, but it is undivided like in Enchelyolepis, 
Macrosemius and Legnonotus (Figs 8C, D). Character 4 is not present in Voelklichthys.

González-Rodríguez \& Reynoso (2004) and González-Rodríguez et al. (2004) characterized the Macrosemiidae by an open mandibular sensory canal, a divided dorsal fin (not in Macrosemius and Legnonotus; Figs 7A, B) and a low number (11-13) of caudal fin rays, but Histionotus, Propterus, and Legnonotus possess more rays (Figs 7A, B) like the outgroup, Semionotus. Voelklichthys n. gen. does not present an open mandibular canal and the number of caudal fin rays is 19. Cavin (2010) interpreted as macrosemiid characters the absence of the parietal [= postparietal here] portion of the supraorbital canal, the absence of a suborbital bone, the lengthened ethmoid region, and an independent and large quadratojugal. Voelklichthys apparently shares only two of these features with macrosemiids (the absence of the parietal portion of the supraorbital canal (Fig. 4) and a suborbital bone). The condition of the quadratojugal is unknown in the new fish.

In conclusion:

1. The morphology of macrosemiiforms is incompletely known and apparently is more diversified and complicated as previously thought. This is not a task to be easily resolved because of condition of incomplete preservation, and due to the fact that numerous specimens have preserved the whole squamation so that the internal anatomy of the vertebral column and associate structures, and the endoskeletons of the fins are hidden by scales.

2. Currently, the macrosemiiforms are characterized by three synapomorphies (Grande 2010), two of which are present in Voelklichthys (e.g., an incomplete circumorbital ring because the lateral edge of frontal bone [of traditional terminology] makes up part of orbital margin, so that the anterior part of the ring is absent); supramaxillary bone absent). The third character cannot be determined in the new fish because the coronoid bones and their dentition are not observed due to condition of preservation.

3. Any of the macrosemiiform groups can be clearly defined or characterized at present, including the best-know family Macrosemiidae. Characters used by different authors to characterize macrosemiids up to now are not consistent within the group and some are weak (highly homoplastic). Voelklichthys n. gen. shares a few characters with macrosemiids and others with uarbryichthyids but lacks others so that the small fish cannot be placed clearly within the Macrosemiiformes but not outside the order either. Presently, we interpret the fish as a macrosemiiform, but we cannot assign it to any family.

4. Voelklichthys comitatus n. gen. n. sp. presents a combination of unique characters that justify the erection of the new genus and species not only among macrosemiiforms but also among actinopterygians as a whole (see generic diagnosis).

\section{Acknowledgements}

We thank Mr. G. Völkl for the preparation of the specimen and Dr. G. Viohl (former director of the Jura-Museum Eichstätt) for the permission to study the holotype here described. We are grateful to Drs. M. Kölbl-Ebert (Eichstätt), T. zu Oettingen ( $\dagger$ ) and M. Moser (München), M. Mäuser (Bamberg), M. Röper (Solnhofen) and H. Toombs $(\dagger)$ and I. Macadie (formerly at BMNH, London) for providing facilities to study material under their care. Special thanks go to Dr. H. Tischlinger (Stammham) for photographing the specimen under UV and white lights and to Mrs. C. Radtke (Berlin) for the photograph illustrated in Figure 2. We thank Mr. J.-P. Mendau (Berlin) for his valuable help with illustrations based on our original drawings, and Dr. F. Abe Reiko (Lawrence, Kansas) for her assistance with the electronic preparation of the illustrations. Special thanks to Drs. K. Gonzalez-Rodriguez (Pachuca. Mexico), L. Cavin (Geneve, Switzerland), E. Hilton (Virginia, USA) and an anonymous reviewer for their valuable comments. The support provided for a visiting research grant from the Alexander von Humboldt Foundation (Bonn) to G. Arratia, and NSF EF-0431262 are greatly appreciated.

\section{References}

Arratia, G. 1997. Basal teleosts and teleostean phylogeny. - Palaeo Ichthyologica 7: 1-168.

Arratia, G. 2000a. New teleostean fishes from the Jurassic of southern Germany and the systematic problems concerning the 'pholidophoriforms'. - Paläontologische Zeitschrift 74: 113-143.

Arratia, G. 2000b. Remarkable teleostean fishes from the Late Jurassic of southern Germany and their phylogenetic relationships. Mitteilungen aus dem Museum für Naturkunde in Berlin, Geowissenschaftliche Reihe 3: 137-179.

Arratia, G. 2008. Actinopterygian postcranial skeleton with special reference to the diversity of fin ray elements, and the problem of identifying homologies. In Arratia, G., Schultze, H.-P. \& Wilson, M. V. H. (eds). Mesozoic Fishes 4 - Homology and Phylogeny. Verlag Dr. F. Pfeil, München: pp. 49-101.

Arratia, G. \& Schultze, H.-P. 1992. Reevaluation of the caudal skeleton of certain actinopterygian fishes. III. Salmonidae. Homologization of caudal skeletal structures. - Journal of Morphology 214: $1-63$.

Arratia, G., Schultze, H.-P. \& Casciotta, J. 2001. Vertebral column and associates elements in dipnoans and comparison with other fishes. Development and homology. - Journal of Morphology 250 (2): 101-172.

Balon, E. K. 1999. Alternative ways to become a juvenile or a definitive phenotype (and some persisting linguistic offenses). - Environmental Biology of Fishes 56: 17-38.

Bartram, A. W. H. 1977a. The Macrosemiidae, a Mesozoic family of holostean fishes. - Bulletin of the British Museum (Natural History), Geology series 29 (2): 137-234.

Bartram, A. W. H. 1977b. A problematical Upper Cretaceous holostean fish genus Aphanepygus. - Journal of Natural History 11: $361-370$.

Beltan, L. 1984. A propos d'un poisson volant biplan de l'Eotrias du NW de Madagascar. - Annales de la Société Géologique du Nord 103: 75-82.

Beltan, L. 1996. Overview of systematics, paleobiology, and paleoecology of Triassic fishes of northwestern Madagascar. In Arratia, G. \& Viohl, G. (eds). Mesozoic Fishes - Systematics and Paleoecology. Verlag Dr. F. Pfeil, München: pp. 479-500.

Brito, P. M. 2000. A new halecomorph with two dorsal fins, Placidichthys bidorsalis n. g., n. sp. (Actinopterygii: Halecomorphi) from the Lower Cretaceous of the Araripe Basin, northeast Brazil. - Comptes rendus de 1'Académie des Sciences, série II, Sciences de la Terre et des Planetes 331: 749-754. 
Brito, P. M. \& Alvarado-Ortega, J. 2008. A new species of Placidichthys (Halecomorphi: Ionoscopiformes) from the Lower Cretaceous Marizal Formation, northeastern Brazil, with a review of the biogeographical distribution of the Ophiopsidae. - Geological Society, London, Special Publications 295: 145-154.

Carroll, R. 1988. Vertebrate Paleontology and Evolution. W. H. Freeman and Co., New York.

Cavin, L. 2010. Diversity of Mesozoic semionotiform fishes and the origin of gars (Lepisosteidae). - Naturwissenschaften 97 (12): $1035-1040$.

Chiappe, L. M. \& Göhlich, U. B. 2010. Anatomy of Juravenator starki (Theropoda: Coelurosauria) from the Late Jurassic of Germany. Neues Jahrbuch für Geologie und Paläontologie, Abhandlungen 258 (3): 257-296.

Cope, E. D. 1872. Observations on the systematic relations of the fishes. - Proceedings of the American Association for the Advancement of Science 20: 317-343.

Cope, E. D. 1887. Zittel's Manual of Palaeontology. - American Naturalist 17: 1014-1019.

Göhlich, U. B. \& Chiappe, L. M. 2006. A carnivorous dinosaur from the Late Jurassic Solnhofen archipelago. - Nature 440: 329-332.

Göhlich, U. B, Tischlinger, H. \& Chiappe, L. M. 2006. Juravenator starki (Reptilia, Theropoda), ein neuer Raubdinosaurier aus dem Oberjura der Südlichen Frankenalb (Süddeutschland): Skelettanatomie und Weichteilbefunde. - Archaeopteryx 24: 1-26.

González-Rodríguez, K. \& Reynoso, V.-H. 2004. A new Notagogus (Macrosemiidae, Halecostomi) species from the Albian Tlayúa Quarry, Central Mexico. In Arratia, G. \& Tintori, A. (eds). Mesozoic Fishes 3 - Systematics, Paleoenvironments and Biodiversity. Verlag Dr. F. Pfeil, München: pp. 265-278.

González-Rodríguez, K., Applegate, S. P. \& Espinosa-Arrubarrena, L. 2004. A New World macrosemiid (Neopterygii: Halecostomi) in the Albian of Tepexi de Rodríguez, Puebla, México. - Journal of Vertebrate Paleontology 24 (2): 281-289.

Grande, L. 2010. An empirical synthetic pattern study of gars (Lepisosteiformes) and closely related species, based mostly on skeletal anatomy. The resurrection of Holostei. - American Society of Ichthyologists and Herpetologists, Special Publication 6, Supplementary Issue to Copeia 10 (2A): I-X, 1-871.

Jollie, M. 1962. Chordate Morphology. Reinhold Publishing Co., New York.

López-Arbarello, A. \& Sferco, E. 2011. New semionotiform (Actinopterygii: Neopterygii) from the Late Jurassic of southern Germany. - Journal of Systematic Palaeontology 9 (2): 197-215.

Müller, J. 1845. Über den Bau und die Grenzen der Ganoiden und das natürliche System der Fische. - Abhandlungen der Akademie der Wissenschaften zu Berlin (1844) 1845: 117-216.

Murray, A. M. \& Wilson, M. V. H. 2009. A new Late Cretaceous macrosemiid fish (Neopterygii, Halecostomi) from Morocco, with temporal and geographical range extensions for the family. - Palaeontology 52 (2): 429-440.

Nelson, J. S. 2006. Fishes of the World. 4th ed. John Wiley and Sons, Hoboken, New Jersey.

Saint-Seine, M. P. de. 1949. Les poissons des calcaires lithographiques de Cerin. - Nouvelles Archives du Muséum d' Histoire Naturelle de Lyon, Fascicule II: 1-355.

Schultze, H.-P. 1966. Morphologische und histologische Untersuchungen an Schuppen mesozoischer Actinopterygier (Uebergang von Ganoid- zu Rundschuppen). - Neues Jahrbuch für Geologie und Paläontologie, Abhandlungen 126 (3): 232-314.

Schultze, H.-P. 1993. Pattern of Diversity in the Skull of Jawed Fishes. In Hanken, J. \& Hall, B. K. (eds). The Skull, Vol. 2: Patterns of Structural and Systematic Diversity. University of Chicago Press, Chicago/London: pp. 189-254.

Schultze, H.-P. 1996. The scales of Mesozoic actinopterygians. In Arratia, G. \& Viohl. G. (eds). Mesozoic Fishes - Systematics and Paleoecology. Verlag Dr. F. Pfeil, München: pp. 83-93.
Schultze, H.-P. 2008. Nomenclature and homologization of cranial bones in actinopterygians. In Arratia, G., Schultze, H.-P. \& Wilson, M. V. H. (eds). Mesozoic Fishes 4 - Homology and Phylogeny. Dr. F. Pfeil, München: pp. 23-48.

Schultze, H.-P. \& Arratia, G. 1986. Reevaluation of the caudal skeleton of actinopterygian fishes. I. Lepisosteus and Amia. - Journal of Morphology 195: 257-303.

Schultze, H.-P. \& Arratia, G. 1988. Reevaluation of the caudal skeleton of actinopterygian fishes. II. Hiodon, Elops and Albula. Journal of Morphology 195: 257-303.

Schultze, H.-P. \& Arratia, G. 1989. The composition of the caudal skeleton of teleosts (Actinopterygii, Osteichthyes). - Zoological Journal of Linnean Society of London 97: 89-231.

Schweigert, G. 2007. Ammonite biostratigraphy as a tool for dating Upper Jurassic lithographic limestones from South Germany first results and open questions. - Neues Jahrbuch für Geologie und Paläontologie, Abhandlungen 245 (1): 117-125.

Thies, D. \& Zapp, M. 1997. Ein Lepidotes (Actinopterygii, $\dagger$ Semionotiformes) aus den Plattenkalken (Oberjura, oberes Kimmeridgium) bei Schamhaupten (Süddeutschland). - Archaeopteryx 15: $11-26$.

Thiollière, V. 1858. Notes sur les poissons fosssiles du Bugey, et sur l'application de la méthode de Cuvier à leur classement. - Bulletin de la Société géologique de France, Paris 15: 782-793.

Tintori, A. \& Sassi, D. 1992. Thoracopterus Bronn (Osteichthyes: Actinopterygii): A gliding fish from the Upper Triassic of Europe. Journal of Vertebrate Paleontology 12 (3): 265-283.

Tischlinger, H. 2002. Der Eichstätter Archaeopteryx im langwelligen UV-Licht. - Archaeopteryx 20: 21-38.

Tischlinger, H. 2005. Ultraviolet Light Investigations of Fossils from the Upper Jurassic Plattenkalks of Southern Frankonia. - Zitteliana B 26: 26.

Tischlinger, H. \& Göhlich, U. B. 2007. Dinosaurier im Altmühljura. Globulus - Beiträge der natur- und kulturwissenschaftlichen Gesellschaft 13: 73-82.

Tischlinger, H., Göhlich, U. B. \& Chiappe, L. M. 2006. Borsti, der Dinosaurier aus dem Schambachtal: Erfolgsstory mit Hindernissen. - Fossilien 2006 (5): 277-287.

Urho, L. 2002. Characters of larvae - what are they? - Folia Zoologica 51 (3): 161-186.

Viohl, G. 1996. The paleoenvironment of the Late Jurassic fishes from the southern Franconian Alb (Bavaria, Germany). In Arratia, G. \& Viohl, G. (eds). Mesozoic Fishes - Systematics and Paleoecology. Verlag Dr. F. Pfeil, München: pp. 513-528.

Viohl, G. 1999. Fund eines neuen kleinen Theropoden. - Archaeopteryx 17: $18-19$.

Viohl, G. 2007. Schamhaupten, an outstanding Fossil-Lagerstätte in a silicified Plattenkalk around the Kimmeridgian-Tithonian boundary (Southern Franconian Alb, Bavaria). - Neues Jahrbuch für Geologie und Paläontologie, Abhandlungen 245: 127-142.

Viohl, G. \& Zapp, M. 2006. Die Fossil-Lagerstätte Schamhaupten (oberstes Kimmeridgium, Südliche Frankenalb, Bayern). - Archaeopteryx 24: 27-78.

Webb, J. F. 1999. Larvae in fish development and evolution. In Hall, B. K. \& Wake, M. H. (eds). The Origin and Evolution of Larval Forms. Academic Press, San Diego: pp. 109-158.

Westoll, T. S. 1943. The origin of tetrapods. - Nature 141: 127.

Wiley, E. O. 2008. Homology, identity and transformation. In Arratia, G., Schultze, H.-P. \& Wilson, M. V. H. (eds). Mesozoic Fishes 4 - Homology and Phylogeny. Verlag Dr. F. Pfeil, München: pp. 922.

Wiley, E. O. \& Johnson, D. 2010. A teleost classification based on monophyletic groups. In Nelson, J., Schultze, H.-P. \& Wilson, M. V. H. (eds). Origin and Phylogenetic Interrelationships of Teleosts. Honoring Gloria Arratia. Verlag Dr. F. Pfeil, München: pp. $123-182$ 
Woodward, A. S. 1895. A contribution to knowledge of the fossil fish fauna of the English Purbeck Beds. - Geological Magazine (4) 2: $145-152$.
Woodward, A. S. 1918. The fossil fishes of the English Wealden and Purbeck formations. Part 2. - Palaeontographical Society, Monographs, London: 49-104. 